\title{
The effects of springtime mid-latitude storms on trace gas composition determined from the MACC reanalysis
}

\author{
K. E. Knowland ${ }^{1}$, R. M. Doherty ${ }^{1}$, and K. I. Hodges ${ }^{2}$ \\ ${ }^{1}$ School of Geosciences, University of Edinburgh, Edinburgh, UK \\ ${ }^{2}$ Department of Meteorology, University of Reading, Reading, UK \\ Correspondence to: K. E. Knowland (k.e.knowland@sms.ed.ac.uk)
}

Received: 8 August 2014 - Published in Atmos. Chem. Phys. Discuss.: 28 October 2014

Revised: 19 February 2015 - Accepted: 17 March 2015 - Published: 31 March 2015

\begin{abstract}
The relationship between springtime air pollution transport of ozone $\left(\mathrm{O}_{3}\right)$ and carbon monoxide $(\mathrm{CO})$ and midlatitude cyclones is explored for the first time using the Monitoring Atmospheric Composition and Climate (MACC) reanalysis for the period 2003-2012. In this study, the most intense spring storms (95th percentile) are selected for two regions, the North Pacific (NP) and the North Atlantic (NA). These storms $(\sim 60$ storms over each region) often track over the major emission sources of East Asia and eastern North America. By compositing the storms, the distributions of $\mathrm{O}_{3}$ and $\mathrm{CO}$ within a "typical" intense storm are examined. We compare the storm-centered composite to background composites of "average conditions" created by sampling the reanalysis data of the previous year to the storm locations. Mid-latitude storms are found to redistribute concentrations of $\mathrm{O}_{3}$ and $\mathrm{CO}$ horizontally and vertically throughout the storm. This is clearly shown to occur through two main mechanisms: (1) vertical lifting of $\mathrm{CO}$-rich and $\mathrm{O}_{3}$-poor air isentropically, from near the surface to the mid- to uppertroposphere in the region of the warm conveyor belt; and (2) descent of $\mathrm{O}_{3}$-rich and CO-poor air isentropically in the vicinity of the dry intrusion, from the stratosphere toward the mid-troposphere. This can be seen in the composite storm's life cycle as the storm intensifies, with area-averaged $\mathrm{O}_{3}$ (CO) increasing (decreasing) between 200 and $500 \mathrm{hPa}$. The influence of the storm dynamics compared to the background environment on the composition within an area around the storm center at the time of maximum intensity is as follows. Area-averaged $\mathrm{O}_{3}$ at $300 \mathrm{hPa}$ is enhanced by 50 and $36 \%$ and by 11 and $7.6 \%$ at $500 \mathrm{hPa}$ for the NP and NA regions, respectively. In contrast, area-averaged $\mathrm{CO}$ at $300 \mathrm{hPa}$ decreases by $12 \%$ for NP and $5.5 \%$ for NA, and area-averaged
\end{abstract}

$\mathrm{CO}$ at $500 \mathrm{hPa}$ decreases by $2.4 \%$ for NP while there is little change over the NA region. From the mid-troposphere, $\mathrm{O}_{3}$ rich air is clearly seen to be transported toward the surface, but the downward transport of CO-poor air is not discernible due to the high levels of $\mathrm{CO}$ in the lower troposphere. Areaaveraged $\mathrm{O}_{3}$ is slightly higher at $1000 \mathrm{hPa}(3.5$ and $1.8 \%$ for the NP and NA regions, respectively). There is an increase of $\mathrm{CO}$ at $1000 \mathrm{hPa}$ for the NP region $(3.3 \%)$ relative to the background composite and a slight decrease in area-averaged $\mathrm{CO}$ for the NA region at $1000 \mathrm{hPa}(-2.7 \%)$.

\section{Introduction}

Tropospheric ozone $\left(\mathrm{O}_{3}\right)$ and carbon monoxide $(\mathrm{CO})$ are relatively long-lived air pollutants, especially when in the free troposphere (Monks et al., 2009). In the troposphere, $\mathrm{O}_{3}$ is photochemically produced from both anthropogenic precursor sources $\left(\mathrm{CO}\right.$ and nitrogen oxides $\left.\left(\mathrm{NO}_{\mathrm{x}}=\mathrm{NO}+\mathrm{NO}_{2}\right)\right)$ and natural precursor sources (e.g., $\mathrm{NO}_{\mathrm{x}}$ from lightning and soils, and volatile organic carbons (VOCs) in the presence of $\mathrm{NO}_{\mathrm{x}}$ ). Production of $\mathrm{CO}$ is the result of incomplete combustion of fossil fuel and biomass burning, as well as the oxidation of VOCs (Holloway et al., 2000; Kumar et al., 2013). Air quality standards have been set for these pollutants as they are harmful to human health, crops, and other vegetation.

Meteorological conditions play an important role in the intercontinental transport of pollutants. With lifetimes of a couple of weeks $\left(\mathrm{O}_{3}\right)$ to a couple of months $(\mathrm{CO}), \mathrm{O}_{3}$ and $\mathrm{CO}$ can be transported over large distances (Akimoto, 2003). Air in the boundary layer mixes with the rest of the troposphere by frontal lifting or convection (Cooper et al., 2001; Li et al., 
2005; Jia et al., 2008). A common conceptual Lagrangian model of synoptic-scale low-pressure systems in the midlatitudes (hereafter referred to as storms) consists of several airstreams including the warm conveyor belt (WCB: Harrold, 1973), cold conveyor belt (CCB: Carlson, 1980), and dry intrusion (DI: Browning, 1997). Polluted (CO-rich) air from the boundary layer is lofted up to the free troposphere by way of the WCB (Stohl and Trickl, 1999; Cooper et al., 2001), which begins in the warm sector, ahead of the associated cold front. The WCB can be identified by the strong ascent along the isentropes above the warm front (Catto et al., 2010). This occurs above the CCB, a low-level rearward jet around the storm, found north of the warm front (Cooper et al., 2001). Most of the conceptual models show there should be anticyclonic ascent of the CCB in the midtroposphere (e.g., Carlson, 1980; Cooper et al., 2001, 2002b); however, Schultz (2001) highlights there are actually few cases that find the CCB turns anticyclonically. In a developed cyclone, the WCB is found within the main body of the cloud (Cooper et al., 2001) and makes up the "cloud head" in the mid- to upper-troposphere, as seen in satellite imagery (Catto et al., 2010). However, the DI can be identified as descending stratospheric cold air with low relative humidity at the rear of the storm (Cooper et al., 2001; Catto et al., 2010). Ozone, which is abundant in the stratosphere, can be transported across the tropopause during synoptic-scale exchanges (e.g., Danielsen, 1968, 1980; Holton et al., 1995) or convection (Gray, 2003; Tang et al., 2011). The DI is an example of the former, wherein stratospheric air descends isentropically into the troposphere in what are known as tropopause folds (Holton et al., 1995). This occurs on the westward side of the upper-level trough (Holton et al., 1995), an important feature of storms. Therefore, the DI can increase $\mathrm{O}_{3}$ throughout the troposphere with the passage of storms (Danielsen, 1980; Holton et al., 1995; Cooper et al., 2004a; Lin et al., 2012a).

Over the last century, $\mathrm{O}_{3}$ measured at surface sites has increased in the Northern Hemisphere (NH). The increase has been attributed to increasing anthropogenic precursors (e.g., Lamarque et al., 2005; Horowitz, 2006; Oltmans et al., 2006). However, in recent decades, strict policies have reduced emissions in North America and Europe. This has had a positive effect on rural observation sites in eastern USA (trends in $\mathrm{O}_{3}$ are decreasing or remaining constant; Cooper et al., 2012) and in Europe (baseline $\mathrm{O}_{3}$ measured at Mace Head, a remote site on the west coast of Ireland, has begun to stabilize; Derwent et al., 2013). However, Asian countries do not have such restrictions and $\mathrm{O}_{3}$ measured at western US rural sites, downwind of Asia, is still increasing (Cooper et al., 2012). The transpacific transport of Asian pollutants is a big concern for air quality in North America (Zhang et al., 2008). Measurements at remote sites (where there is negligible influence of locally produced emissions) show that the longrange transport of pollutants from major emission source regions can adversely affect the ability of distant communities to maintain their air quality standards ( $\mathrm{Li}$ et al., 2002,
2005; Stohl, 2001; Stohl et al., 2002a; Cooper et al., 2010; Parrish et al., 2012). There is strong evidence both from observations and modeling that the WCB is important to the long-range transport of air pollutants due to its ability to rapidly bring pollutants from the surface to the upper troposphere, compared to the CCB which only lofts pollutants at low levels (e.g., Stohl, 2001; Stohl et al., 2002a; Li et al., 2002, 2005; Eckhardt et al., 2004). The DI also has shown to be important for long-range transport from Asia to western North America, with polluted air and stratospheric air descending behind the cold front (Lin et al., 2012b), having been transported across the Pacific Ocean in the mid- to upper troposphere (Brown-Steiner and Hess, 2011). In addition, the importance of frontal passage (and, therefore, storm) frequency in ventilating the boundary layer of pollutants, which have built-up during anticyclonic conditions, has been well documented (e.g., Mickley et al., 2004; Hegarty et al., 2007; Leibensperger et al., 2008). Furthermore, the different transport pathways of constituents can be linked to atmospheric circulation changes associated with the different phases of teleconnection patterns, such as the North Atlantic Oscillation (NAO), El Niño/Southern Oscillation (ENSO), and the Pacific-North American (PNA) pattern (e.g., Li et al., 2002; Creilson et al., 2003; Eckhardt et al., 2004; Lamarque and Hess, 2004; Christoudias et al., 2012; Pausata et al., 2012; Lin et al., 2014).

Although storms are generally more intense in wintertime, spring (MAM) is perhaps more interesting as it is the season when surface $\mathrm{O}_{3}$ peaks in much of the NH's mid-latitudes, albeit less so in continental interiors (Monks, 2000). More importantly, spring tends to be the season of maximum intercontinental $\mathrm{O}_{3}$ transport (Monks, 2000; Stohl et al., 2002a). Observations also suggest a maximum in springtime transport of stratospheric $\mathrm{O}_{3}$ through tropopause folds (Holton et al., 1995; Cooper et al., 2002a). Cooper et al. (2002a) found CO levels are highest within North Atlantic (NA) storms in the spring (compared to late summer/early autumn) due to storms passing closer to emission sources and to reduced oxidation of $\mathrm{CO}$ by $\mathrm{OH}$ radicals compared to summer/early autumn.

Due to the importance of storms in transporting $\mathrm{O}_{3}$ and $\mathrm{CO}$ pollution in the $\mathrm{NH}$ springtime, the aim of this paper is to investigate the effect of airstream transport mechanisms on $\mathrm{O}_{3}$ and $\mathrm{CO}$ within intense springtime storms. Trajectory analysis, using Lagrangian dispersion models (Stohl et al., 1998, 2002b) have been used previously to look at transport pathways of pollutants in individual events or short time periods (e.g., Cooper et al., 2002a, 2004b, a; Owen et al., 2006) or over regions frequented by WCBs or DIs (e.g., Stohl and Trickl, 1999; Stohl, 2001; Eckhardt et al., 2004). Our study uses the Monitoring Atmospheric Composition and Climate (MACC) reanalysis with a storm tracking algorithm to identify intense storms and to view the pollutants within the storm and attribute them to different air streams. Our study benefits from large sample size capabilities from which we are able to 
study many storms of similar characteristics over a 10 -year period.

The paper continues with Sect. 2, which describes the MACC reanalysis data set and the storm tracking algorithm. In particular, we describe two methods of storm compositing used to link the distribution of $\mathrm{O}_{3}$ and $\mathrm{CO}$ with intense storms (95th percentile) over the NH's oceanic basins using the MACC reanalysis fields. The results of the storm track compositing on the meteorological fields and composition are related to the different airstreams of the storms in Sect. 3 with discussion and conclusions in Sect. 4.

\section{Data and methods}

\subsection{The MACC reanalysis data set}

This study uses the MACC reanalysis data set (Inness et al., 2013), which covers the period 2003-2012. MACC is a continuation of the Global and Regional Earth-System Monitoring Using Satellite and In situ Data (GEMS) project (Hollingsworth et al., 2008) to forecast chemically reactive gases (Flemming et al., 2009; Inness et al., 2009), greenhouse gases (Engelen et al., 2009), and aerosols (Benedetti et al., 2009; Morcrette et al., 2009). The MACC reanalysis data are produced with the GEMS Integrated Forecast System (IFS cycle 36r1) model of the European Centre for Medium-Range Weather Forecasts (ECMWF). In terms of meteorology, the MACC data are similar to the widely used ERA-Interim reanalysis (Dee et al., 2011), which uses an earlier IFS cycle (Cy31r2; a history of changes made to the ECMWF IFS is available at http://www.ecmwf.int/en/forecasts/ documentation-and-support/changes-ecmwf-model). The MACC model has a horizontal resolution of T255 (N128, nominally $\sim 0.7^{\circ}$ ) with 60 sigma-pressure levels from the surface to $0.1 \mathrm{hPa}$ (Inness et al., 2013), which is the same as ERA-Interim (Dee et al., 2011). The temporal resolution of the data set is 6 hourly.

MACC includes fields for the reactive gas species $(\mathrm{CO}$, $\mathrm{O}_{3}, \mathrm{NO}_{\mathrm{x}}$, and formaldehyde) and uses the 4-D variational data assimilation (4-D-Var) system to assimilate observations of the species from total and partial column satellite retrievals (Flemming et al., 2009; Inness et al., 2013) as well as the standard meteorological observations. The IFS atmospheric model is two-way coupled to a modified version (Stein, 2009; Stein et al., 2012) of the Model for OZone And Related chemical Tracers (MOZART-3; Kinnison et al., 2007) chemistry transport model (CTM). The IFS provides the CTM with the meteorological fields while the chemical reactions of 115 species in the troposphere and stratosphere are calculated in the CTM (Stein, 2009; Stein et al., 2012; Inness et al., 2013). The two models are run in parallel and, every hour, the CTM provides the IFS system with updated chemical tendencies which are used to constrain the assimi- lated species $\left(\mathrm{CO}, \mathrm{O}_{3}\right.$, and $\left.\mathrm{NO}_{\mathrm{x}}\right)$, and in turn the IFS provides the CTM with mixing ratios based on advection (Flemming et al., 2009; Stein, 2009; Stein et al., 2012).

The anthropogenic emission data set used as input for MACC (MACCity; Granier et al., 2011) was produced by linear interpolation of the 2005 and 2010 emissions of the future Representative Concentration Pathways (RCP; Moss et al., 2010) 8.5 scenario to yearly emissions (Inness et al., 2013). The Global Fire Assimilation System (GFAS), based on Moderate Resolution Imaging Spectroradiometer (MODIS) satellite daily observations of fires, was used from 2009 onwards to derive biomass-varying burning emissions. Prior to 2009, monthly emissions from the Global Fire Emissions Database (GFED 3.0; van der Werf et al., 2010) were used for biomass burning emissions (Kaiser et al., 2011). An updated version (Barkley, 2010) of the Model of Emissions of Gases and Aerosols from Nature version 2 (MEGAN-v2; Guenther et al., 2006, http://acd.ucar.edu/ quenther/MEGAN/MEGAN.htm) was used for biogenic emissions. Natural emissions, such as from soil, used in the CTM came from the "Present and future surface emissions of atmospheric compounds" (POET; Granier et al., 2005) project, and $\mathrm{NO}_{\mathrm{x}}$ from lightning is parameterized as in Price et al. (1997).

The MACC reanalysis has been validated against multiple observational networks of ground-based measurements, ozonesondes, commercial flights, and satellite data (Inness et al., 2013; http://www.gmes-atmosphere.eu/services/aqac/ global_verification/). Stratospheric $\mathrm{O}_{3}$ has been compared to ozonesondes and Atmospheric Chemistry Experiment Fourier transform spectrometer (ACE-FTS; Dupuy et al., 2009) data and found to have biases of $\pm 10 \%$. Tropospheric $\mathrm{O}_{3}(1000$ to $200 \mathrm{hPa}$ ) in the $\mathrm{NH}$ has biases of $\pm 10 \%$ (with higher biases in tropics) when compared to ozonesondes and MOZAIC (Measurement of Ozone and Water Vapour by Airbus In-Service Aircraft; Marenco et al., 1998; Nedelec et al., 2003) profiles. The positive biases in tropospheric $\mathrm{O}_{3}$ in the regions of high emissions when comparing MACC to MOZAIC are likely due to low $\mathrm{NO}_{\mathrm{x}}$ in the MACC model (Inness et al., 2013). The reanalysis CO at the surface agreed well both seasonally and in magnitude when compared to observed $\mathrm{CO}$ at three (Mace Head, Ireland; Key Biscayne, Florida, USA; Tenerife, Spain) out of four (South Pole) National Oceanic and Atmospheric Administration Global Monitoring Division (NOAA/GMD) station sites (Inness et al., 2013). When compared to the flight data in the extratropics, MACC CO was lower (higher) between 1000 and $300 \mathrm{hPa}(300-200 \mathrm{hPa})$. From these and other validation studies, there are no extreme biases in $\mathrm{O}_{3}$ or $\mathrm{CO}$ considered in our study.

For this study, meteorological and chemical variables from the MACC reanalysis for 2003-2012 were extracted on 12 pressure levels from 1000 to $200 \mathrm{hPa}$. These variables included zonal and meridional wind components $(u$ and $v$, respectively), vertical velocities $(\omega)$, temperature $(T)$, spe- 
cific humidity $(q)$, and $\mathrm{O}_{3}$ and $\mathrm{CO}$ mixing ratios. In addition, mean sea level pressure (MSLP) was extracted. Relative vorticity at $850 \mathrm{hPa}\left(\zeta_{850}\right)$ was extracted for storm identification. The MACC reanalysis did not archive potential vorticity (PV) data. The storm tracking algorithm detects the same intense storms in the ERA-Interim reanalysis for the same period as in the MACC reanalysis (not shown); therefore, we used PV data from ERA-Interim to determine the dynamical tropopause at PV $=2$ PVU $\left(1 \mathrm{PVU}=10^{-6} \mathrm{~m}^{2} \mathrm{~kg}^{-1} \mathrm{~s}^{-1}\right)$ (Holton et al., 1995).

\subsection{Storm identification}

The objective feature tracking algorithm, TRACK (Hodges, 1994, 1995, 1999), was used to identify mid-latitude storms in the MACC reanalysis as maxima in $\zeta_{850}$. Traditionally, tracking methods have used minima in MSLP (e.g., Serreze, 1995; Geng and Sugi, 2001; Bauer and Del Genio, 2006), but the $\zeta_{850}$ field was used for the following reasons: the $\zeta_{850}$ is less influenced by the large-scale background field, it tends to focus on smaller spatial scales, and it is not an extrapolated field except over the major orography that intersects with the $850 \mathrm{hPa}$ level (Hoskins and Hodges, 2002). Typically storms can be identified much earlier in the vorticity field than in the MSLP field (Hodges et al., 2003; Catto et al., 2010). To be consistent with previous studies in the identification process, the large-scale background field is first removed (planetaryscale waves with total wave number, $n \leq 5$ ), though this is more important for tracking MSLP minima than $\zeta_{850}$ maxima (Hoskins and Hodges, 2002; Catto et al., 2010). Vorticity contains a lot of small-scale features at the T255 resolution of the reanalysis; therefore, the resolution is reduced to T42 using spectral analysis, which focuses on the synoptic scales (Hoskins and Hodges, 2002). The tracking is performed on the unit sphere and the tracks are assembled by minimizing a track smoothness cost function subject to adaptive constraints (Hodges, 1995, 1999). On completion of the tracking, the stationary or short-lived storms are removed, keeping only the storms that travel at least $1000 \mathrm{~km}$ and last for at least 2 days (eight 6 hourly time steps). On average, $431( \pm 14) \mathrm{NH}$ storms that satisfy these criteria are identified in MAM each year for the period 2003-2012. There is a decrease in the number of $\mathrm{NH}$ storms over the 10-year period, but this is not significant $(p>0.1)$.

Two major storm track regions are the focus of this study: the North Pacific (NP) sector $\left(30-80^{\circ} \mathrm{N}, 110^{\circ} \mathrm{E}-130^{\circ} \mathrm{W}\right)$ and the North Atlantic sector $\left(30-80^{\circ} \mathrm{N}, 90^{\circ} \mathrm{W}-30^{\circ} \mathrm{E}\right.$ ) (see Fig. 1a and b). These two regions are selected to capture storms likely to begin over regions of high emissions, move out over the ocean basins, and end near or over downwind continents. The storm tracks that pass through each region are sorted by the maximum $\zeta_{850}$ reached during the storm's lifetime and binned into percentiles: 95th (top 5\% most intense storms), 50th (47.5 to $52.5 \%$ ), and 5th (weakest $5 \%$ of storms). There are about 60 storm tracks in each of these three bins for each region.

\subsection{Storm composites}

There are two ways data can be averaged (hereafter referred to as composited) together: (1) as a single area average of the points in the analysis grid that fall within a given radius of the storm center or (2) by an individual radial gridded data point to provide a 2-D map of the area around the storm center. At each point along the track (defined by the latitude and longitude coordinates of the $\zeta_{850}$ maxima at every time step), a spherical "cap" based on a given radius is used to define the area of coverage by the storm (see Appendix in Bengtsson et al. (2007) for full details on track compositing). For method (1), all values of a given variable (i.e., $\mathrm{O}_{3}$ or $\mathrm{CO}$ ) within a spherical cap are averaged by pressure level to produce a single area-average value (hereafter referred to as aavg- $\mathrm{O}_{3}$ and aavg-CO) for each 6 hourly point along the storm track at each pressure level. We found that a $6^{\circ}$ radius $(\sim 600 \mathrm{~km})$ is most suitable for representing the storm area, with larger radii tending toward background levels of $\mathrm{O}_{3}$ and $\mathrm{CO}$ (Fig. 1c and d) and smaller radii biased by extreme values. The storm track locations as identified on the $850 \mathrm{hPa}$ level are used on all levels between 1000 and $200 \mathrm{hPa}$ to center the spherical cap at these levels. In this fashion, the tilt of the storm (typically toward the northwest with altitude) is not taken into consideration; however, previous studies suggest this should have a minimal effect on the composite results (Bengtsson et al., 2009; Catto et al., 2010). The point along each storm track with the maximum $\zeta_{850}$ is used as a central reference point for compositing the tracks together. The aavg-CO and aavg- $\mathrm{O}_{3}$ from each track are composited by time steps relative to the point of maximum $\zeta_{850}$ to show the evolution of aavg- $\mathrm{O}_{3}$ and aavg-CO throughout the life cycle (from growth to decay) of the composite storm.

Focusing solely on the time of maximum intensity of the storm, method (2) composited each gridded data point separately within the spherical cap. A schematic of the compositing method can be found in Fig. 3 of Catto et al. (2010). Here, the spherical cap is a radial coordinate system which is setup over the poles and then rotated to the point on the track, extracting the data in the region of the point to the new coordinate system (Bengtsson et al., 2007, 2009; Catto et al., 2010). The spherical cap at each point is then further oriented in the direction of storm propagation (Bengtsson et al., 2007, 2009; Catto et al., 2010). This enables the points from different tracks to be composited without introducing a latitudinal bias in the composite. The composite approach will weaken the indication of fronts as the fronts tend to be oriented differently in each storm; however, all points have been oriented in the direction of storm propagation and therefore the loss of such information should be minimized (Bengtsson et al., 2009; Catto et al., 2010; Dacre et al., 2012). Here, a $20^{\circ}$ radius $(\sim 2000 \mathrm{~km})$ spherical cap is used over each track point 
a)

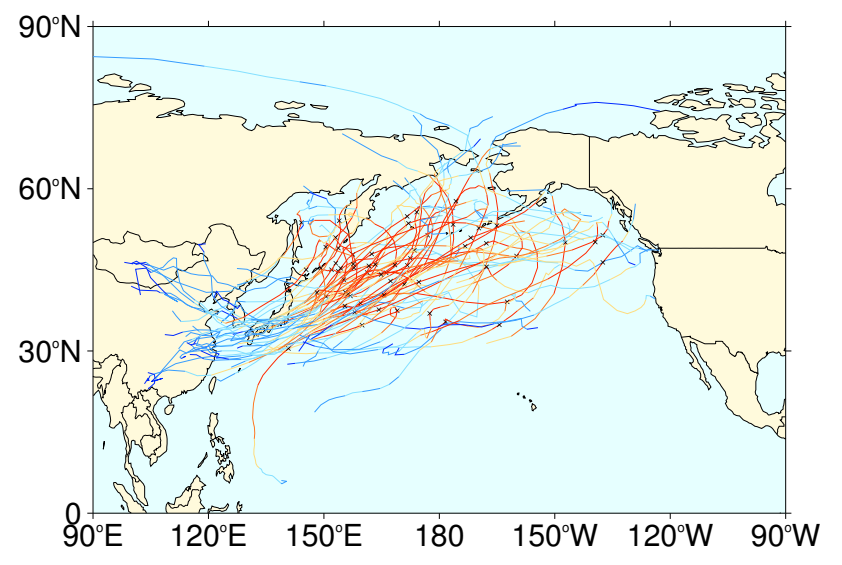

b) NA Storm Tracks

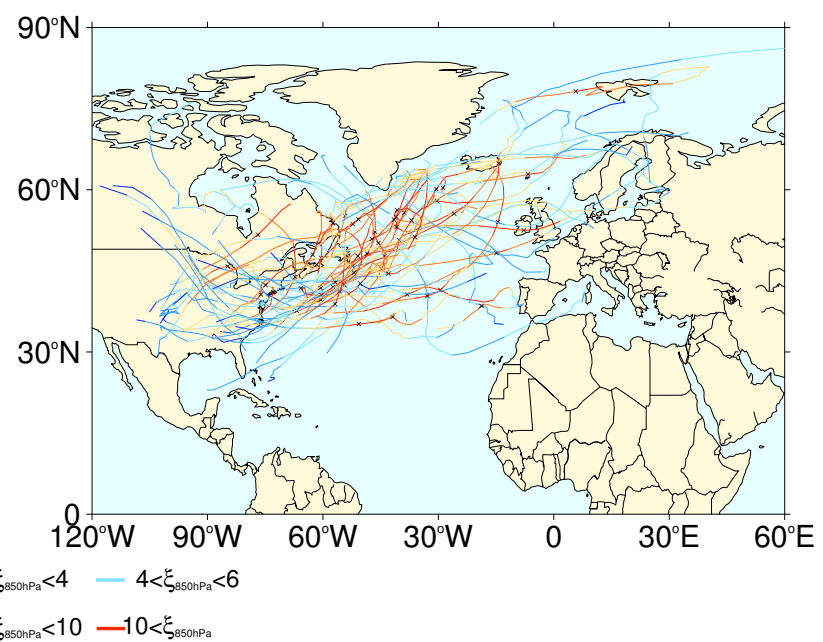

c) $\quad$ Mean $\mathrm{O}_{3}$ profile

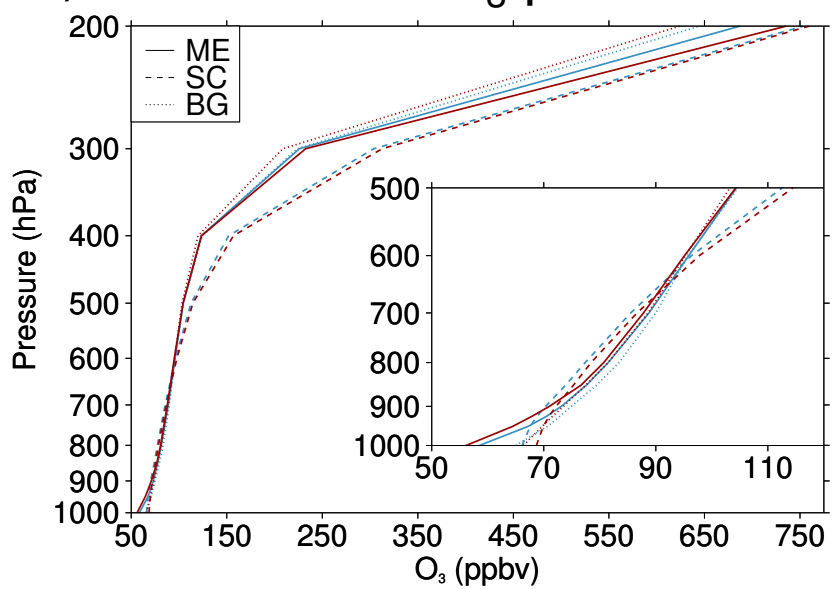

d)

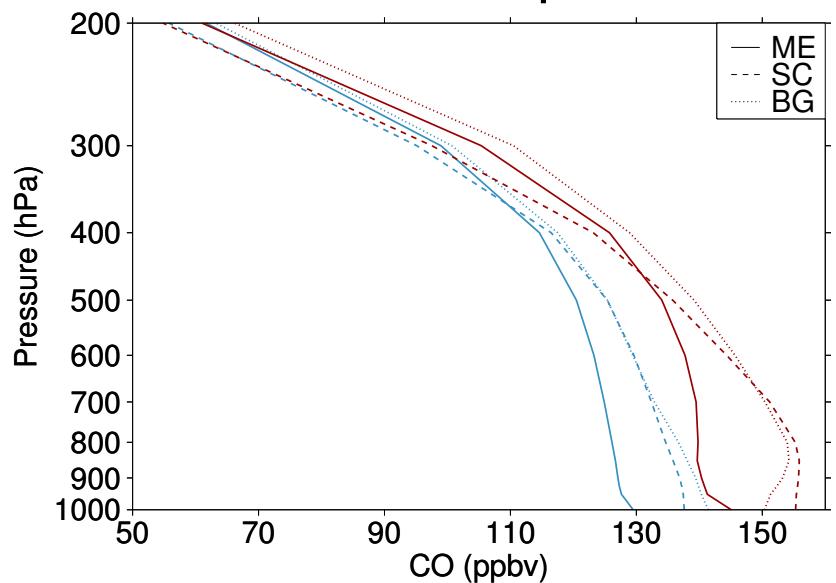

Figure 1. Storm tracks with maximum $\zeta_{850}\left(10^{-5} \mathrm{~s}^{-1}\right)$ in the 95th percentile for MAM during 2003-2012 for (a) NP and (b) NA regions. The time step where maximum $\zeta_{850}$ occurred is marked by an $\mathrm{x}$, and the strength of the storm is indicated by the color (increasing strength from blue to red). The vertical profiles for (c) $\mathrm{O}_{3}$ and (d) $\mathrm{CO}$ for NP (red lines) and NA (blue lines) are shown: the MAM 2003-2012 mean $\mathrm{MACC}_{3}$ and $\mathrm{CO}$ for the NP and NA regions (ME; solid lines), the storm-centered composite aavg-O $\mathrm{O}_{3}$ and aavg-CO (SC; dashed lines), and the background composite aavg- $\mathrm{O}_{3}$ and aavg-CO (BG; dotted lines) at the time of the storm-centered composite maximum $\zeta_{850}$ (see Figs. 2 and 3).

in order to examine the distribution of the chemical species in the vicinity of the storms, both near and far. In addition to the chemical fields, meteorological fields - equivalent potential temperature $\left(\theta_{\mathrm{e}}\right), u, v$, and $\omega$ - were composited. These variables are used to identify the WCB and DI by vertical movement along $\theta_{\mathrm{e}}$ contours and horizontal flow around the storm on the pressure levels. The vertical velocity $(\omega)$ in pressure coordinates is negative for ascent; however, we have multiplied $\omega$ by -1 so that in the rest of the paper ascent is positive and descent is negative. To diagnose the dynamical tropopause, the ERA-Interim reanalysis PV on pressure levels was composited.
The composited storms allow us to have a typical 3-D picture of the $\mathrm{O}_{3}$ and $\mathrm{CO}$ distributions within intense midlatitude storms, throughout the composite life cycle as well as for the associated meteorological fields. In particular, we consider the horizontal and vertical air flow along the conveyor belts described in Sect. 1 .

\subsection{Background "average conditions"}

Grandey et al. (2011) showed the influence of storms on aerosol optical depth over the Atlantic Ocean by comparing storm composites (similar to method (2) described in Sect. 2.3) to composites of "average conditions". The method of Grandey et al. (2011) was used here to create a compos- 

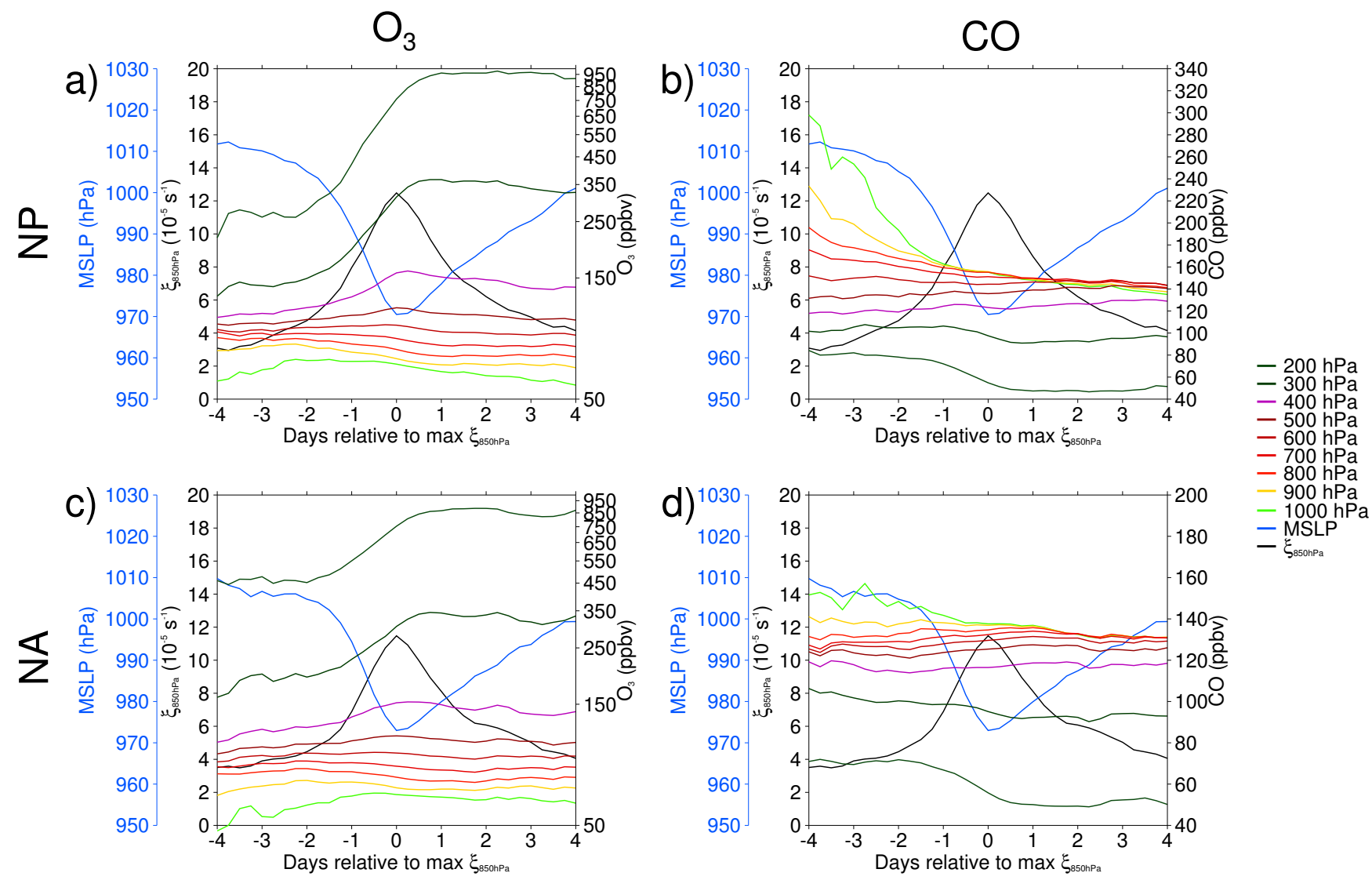

Figure 2. Life cycle of the 95th percentile MAM storm tracks during 2003-2012 for (a, b) NP and (c, d) NA with composite maximum $\zeta_{850}$ (black line), storm-centered composite MSLP (blue line), and storm-centered composite (a, c) aavg-O 3 and (b, d) aavg-CO for nine atmospheric pressure levels (different colored lines). Time steps are every $6 \mathrm{~h}$.

ite of average conditions for the period 2003-2012, whereby the latitude and longitude coordinates for the intense storm tracks selected above were matched to the meteorological and chemical variables of the previous year, i.e., an "offset" year. For the composites of average conditions, the same composite methods described in Sect. 2.3 are used but using the data offset by 1 year; for example, the date and location of the intense storm tracks of 2004 are matched to the meteorology and chemistry fields in 2003.

The composite of the same storm track locations using variables from offset years allows us to distinguish between changes in composition due to horizontal and vertical motions within the intense storms as they evolve as opposed to changes simply in storm track position. In the average condition composites, the stratification of temperature and moisture from the tropics towards the poles will be represented as well as the general westerly winds of the midlatitudes and the composition that would be expected in environments without storms. These meteorological conditions can be clearly seen in Fig. 5. As the intense storm tracks are located in the major storm track regions, there may be a small influence of weaker storms on these composites; however, these composites are not centered on storms when the data were sampled and therefore any storm-related activity should be smoothed out. The interannual variability of the emissions over the 10-year period is included in the average condition composites. The sensitivity to different offset time periods requires further study.

This set of average condition composites will be referred to hereafter as the background composites and the composites described in Sect. 2.3 as the storm-centered composites.

\section{Results}

\subsection{Intense storms in MACC}

The individual storm tracks for the 95th percentile MAM storms over the NP (62 storms) and NA (58 storms) regions are shown in Fig. 1a and b. As expected, these intense storms are located in the major storm track pathways, generally having originated over eastern China or east of the Rocky Mountains, and track northeast with the location of maximum $\zeta_{850}$ typically occurring over the remote ocean. When the storm track locations are compared to the weaker storms, the 50th 


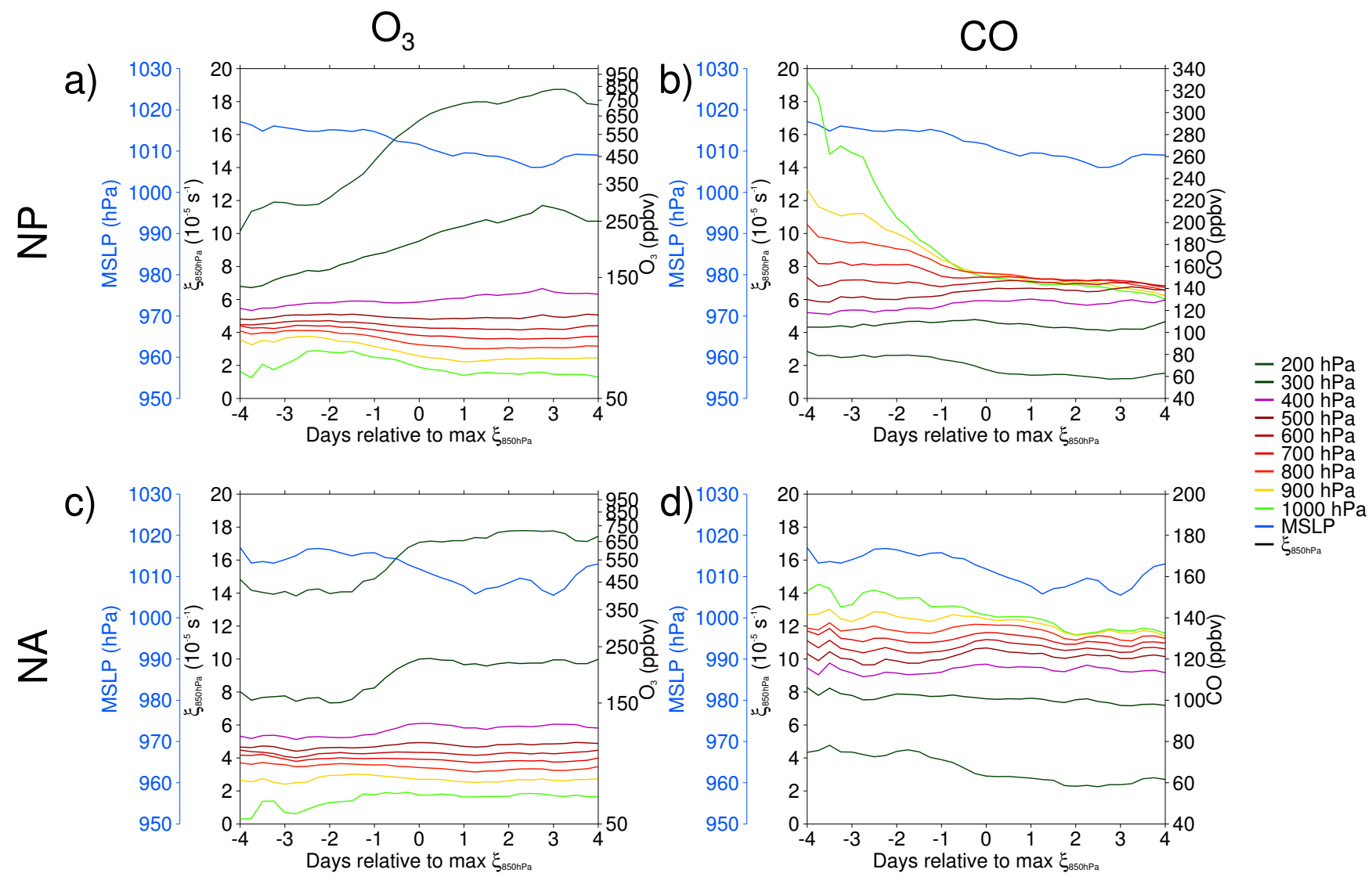

Figure 3. Same as Fig. 2 but for storm track locations with the background meteorology and chemistry.

and 5th percentile tracks are not located solely in the major storm track pathways and the storm tracks in the 5th percentile are generally short-lived weak systems (not shown). This makes the intense storms ideal for compositing as their storm paths and structures are likely to be similar. In addition, the mechanisms for transport within the intense storms will be stronger compared to weaker systems.

Eckhardt et al. (2004) found that WCBs during strong positive NAO winter months are generally more frequent over the North Atlantic (about 12\%) and are more frequent over northern Europe compared to strong negative NAO winter months where WCBs are more frequent over the western North Atlantic. The frequency of the intense springtime storm tracks in each region was tested against different indices to investigate whether stronger storms develop during particular phases. There was no correlation between the frequency of the MAM 95th percentile NA storms and the monthly PC-based NAO index of Hurrell et al. (2003). There are weak or no correlations between the frequency of the MAM 95th percentile NP storms and the monthly PNA index (downloaded from the NOAA Climate Prediction Center) or the monthly Pacific Decadal Oscillation (downloaded from http://jisao.washington.edu/pdo/PDO.latest), respectively. These most intense storms do not show a robust relationship to teleconnection indices; however, the sample size ( $\sim 60$ storms over each region) is small and the criteria to select the storms were not limited to the months of strong teleconnection phases. Further study is required to investigate the spatial relationship among different teleconnection phases, storm tracks, and composition (Knowland et al., 2015).

\subsection{Life cycle of area-average $\mathrm{O}_{3}$ and $\mathrm{CO}$}

Figures 2 and 3 show the storm-centered composite life cycle and the background composite life cycle, respectively, of the 95th percentile MAM storm tracks for both regions based on compositing method (1). There are similarities to the structures of the storm-centered life cycle plots to the background life cycle plots, but the differences are indicative of the storm's effects on the meteorology and composition. The growth and decay of the composite storm can be seen in the increase and decrease of $\zeta_{850}$ (black line, Fig. 2), with the peak (which is greater in NP region than in NA region) indicating the time of maximum $\zeta_{850}$. The time of maximum $\zeta_{850}$ corresponds well with the minimum MSLP (blue line, Fig. 2) in the storm-centered composites as expected (e.g., Bengtsson et al., 2009), whereas the background composite MSLP (blue line, Fig. 3) decreases as expected 
with the storm track locations moving northeastward toward semi-permanent low-pressure regions, i.e., the Aleutian Low and Icelandic Low. The composite aavg-CO and aavg- $\mathrm{O}_{3}$ for each pressure level are shown by the other colored lines (Figs. 2 and 3).

Figure $1 \mathrm{c}$ and $\mathrm{d}$ show mean $\mathrm{O}_{3}$ and $\mathrm{CO}$ profiles for the NP and NA regions over the 10 -year period. Figure 1c shows that the mean $\mathrm{O}_{3}$ is lowest near the surface for both regions and increases with height until stratospheric $\mathrm{O}_{3}$ levels are reached. The converse gradient occurs for the mean $\mathrm{CO}$, with mean $\mathrm{CO}$ decreasing with height away from surface emission sources (Fig. 1d). For the entire life cycle of the storm-centered composites and the background composites, aavg- $\mathrm{O}_{3}$ is also lowest near the surface and increases with height (Figs. 1c, 2a and c, 3a and c). Between 1000 and $300 \mathrm{hPa}$, the mean $\mathrm{CO}$ in the NP region is greater than in the NA region (Fig. 1d). Similarly, the aavg-CO is also greater in the NP region than the NA region throughout the troposphere (Figs. 1d, 2b and d, 3b and d). The highest values of aavg-CO are generally found in the low troposphere and early in the storm-centered and background composite life cycles (Figs. 2b and d, 3b and d), when the storm locations are closer to the emission sources of East Asia and eastern North America.

The values of the background composite aavg- $\mathrm{O}_{3}$ at upper levels (200 and $300 \mathrm{hPa}$; dark green lines, Fig. 3a and c) are well above the chemical tropopause level, often defined as 150 ppb of $\mathrm{O}_{3}$ (Prather et al., 2001), and increase over the life cycle. The large increase in aavg- $\mathrm{O}_{3}$ at upper levels over the life cycle of both composites (Figs. 2a and c, 3a and c) is likely due to the storm locations primarily moving toward the north where the tropopause is lower; therefore the upperlevel pressure surfaces are located higher in the stratosphere, which has higher concentrations of $\mathrm{O}_{3}$. In the storm-centered life cycle plots, there is a steeper gradient compared to the background composites in aavg- $\mathrm{O}_{3}$ at the upper levels (200 and $300 \mathrm{hPa}$ ) and mid-tropospheric levels (400 and $500 \mathrm{hPa}$; Figs. 2a and c, 3a and c) from about 2 days prior to maximum $\zeta_{850}$ until about 1 day after. This is likely due to $\mathrm{O}_{3}$-rich stratospheric air becoming entrained into the storm as part of the DI (Sect. 3.3). The fact that the storm-centered composite aavg- $\mathrm{O}_{3}$ is above or just below $150 \mathrm{ppb}$ at $400 \mathrm{hPa}$ in both regions around the time of maximum $\zeta_{850}$ (Fig. $2 \mathrm{a}$ and $\mathrm{c}$ ) while the background composite aavg- $\mathrm{O}_{3}$ is well below $150 \mathrm{ppb}$ at $400 \mathrm{hPa}$ (Fig. 3a and c) indicates that stratospheric air can reach below $400 \mathrm{hPa}$ as part of the DI in these intense storms. Similarly, at upper levels, aavg-CO decreases are greater in the storm-centered composites (green lines, Fig. 2b and d) than in the background composites (green lines, Fig. $3 b$ and d) likely due to the greater amounts of stratospheric $\mathrm{CO}$-poor air being entrained in the DI. At the time of maximum $\zeta_{850}$, the vertical profiles in Fig. 1c and d of aavg- $\mathrm{O}_{3}$ and aavg-CO for the storm-centered composites display a slightly weaker gradient compared to both regional means in the mid- to upper troposphere while the background composites are gener- ally steeper at these heights (Fig. 1c and d). This further suggests that stratospheric air is reaching these mid-tropospheric heights in the storm-centered composites.

In summary, during the composite storm's life cycle, in the days leading up to maximum $\zeta_{850}$, the increase in aavg$\mathrm{O}_{3}$ and decrease in aavg-CO between 200 and $500 \mathrm{hPa}$ are caused by the DI bringing stratospheric $\mathrm{O}_{3}$-rich and $\mathrm{CO}$-poor air down in tropopause folds, which is likely compounded by the storm's propagation northward where the tropopause is lower. The fact that the DI signal can be seen in the area-averages indicates that it may substantially influence the composition within the storm. The airstream transport is now examined in more detail.

\subsection{Distribution of $\mathrm{O}_{3}$ and $\mathrm{CO}$ within mid-latitude storms}

In this section, the spatial distribution of composite $\mathrm{O}_{3}$ and $\mathrm{CO}$, using method (2), at the time of the storm's maximum intensity is considered. Figure 4 shows the 95th percentile MAM storm-centered composite horizontal distribution of $\mathrm{O}_{3}(\mathrm{a}, \mathrm{c})$ and $\mathrm{CO}(\mathrm{b}, \mathrm{d})$, with horizontal wind vectors and $\theta_{\mathrm{e}}$, for the NP region $(\mathrm{a}, \mathrm{b})$ and the NA region $(\mathrm{c}, \mathrm{d})$ using a $20^{\circ}$ radius cap. Figure 5 shows the same for the background composites, which are free from any major influence from storm dynamics. Figure 6 shows the storm-centered composite minus the background composite anomalies of $\mathrm{O}_{3}, \mathrm{CO}, \omega$, and horizontal winds for both regions. For discussion of the spherical cap we refer to the unit circle with cardinal points (see Fig. 7): west $\left(0^{\circ}\right)$, south $\left(90^{\circ}\right)$, east $\left(180^{\circ}\right)$, and north $\left(270^{\circ}\right)$. The direction of storm propagation is from west to east.

In Fig. 4, the system-relative winds (where the speed of the storm propagation has been subtracted from the winds about each storm before they are composited; Catto et al., 2010; Dacre et al., 2012) show general cyclonic motion around the storm center in the storm-centered composites, with strongest surface winds close to the center between 180 and $315^{\circ}$. At upper levels, the anticyclonic flow in the wind field southeast of the storm center indicates the storm's interaction with the jet in the exit region of the upper-level trough and the end of the WCB (Cooper et al., 2002a, b; Catto et al., 2010; Parrish et al., 2012). In Fig. 5, the background composite winds are very weak at the low altitudes and become stronger westerlies with increasing altitude.

The contours of $\theta_{\mathrm{e}}$ indicate the temperature and moisture differences in the composite's environment. In the stormcentered composites (Fig. 4), the boundaries between the air masses can be identified by the tight gradients in $\theta_{\mathrm{e}}$ (Catto et al., 2010). The approximate surface cold front can be identified on the $1000 \mathrm{hPa}$ level where the gradient of $\theta_{\mathrm{e}}$ is the greatest west of the storm center and where the wind vectors change from cyclonic to anticyclonic southwest of the storm center (Fig. 4). The approximate surface warm front is toward the southeast of the NP storm center and to the 


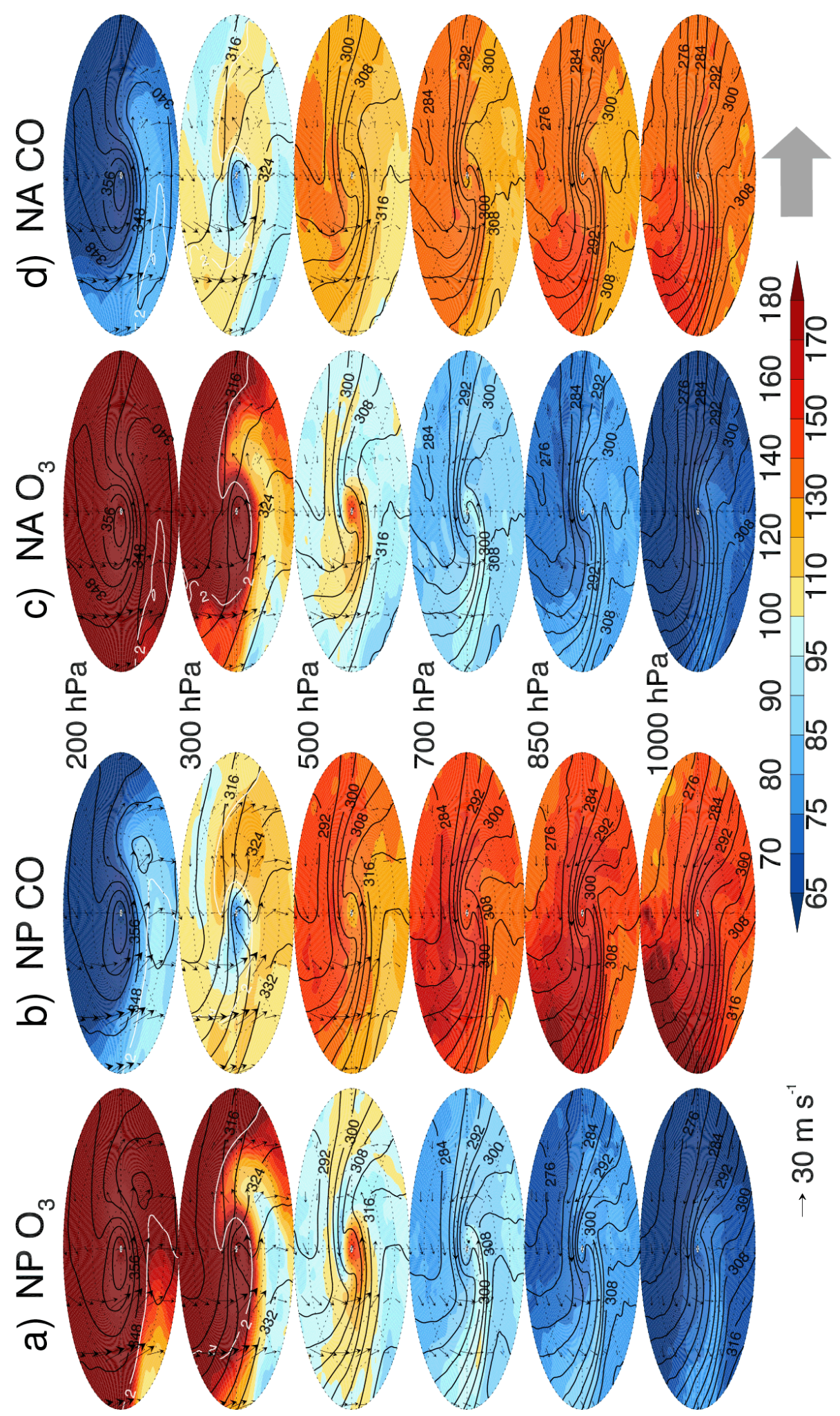

Figure 4. 95th percentile MAM storm tracks during 2003-2012 for (a, b) NP and (c, d) NA storm-centered composites of (a, c) $\mathrm{O}_{3}$, (b, d) $\mathrm{CO}\left(\mathrm{O}_{3}\right.$ and $\mathrm{CO}$ color contours using same color bar, $5 \mathrm{ppb}$ intervals for cool colors and $10 \mathrm{ppb}$ intervals for warm colors), $\theta_{\mathrm{e}}$ (black contour lines; $4 \mathrm{~K}$ intervals), and horizontal wind vectors $\left(30 \mathrm{~m} \mathrm{~s}^{-1}\right.$, reference arrow) on five levels $(1000,850,700,500,300$, and 200 hPa). Dynamical tropopause estimated by the isosurface of 2 PVU (solid white line). Storm propagation is toward the right as indicated by the large grey arrow. Radial dotted lines are plotted every $45^{\circ}$ and dotted circles represent 5,10 , 15 , and $20^{\circ}$ radii from storm center. 


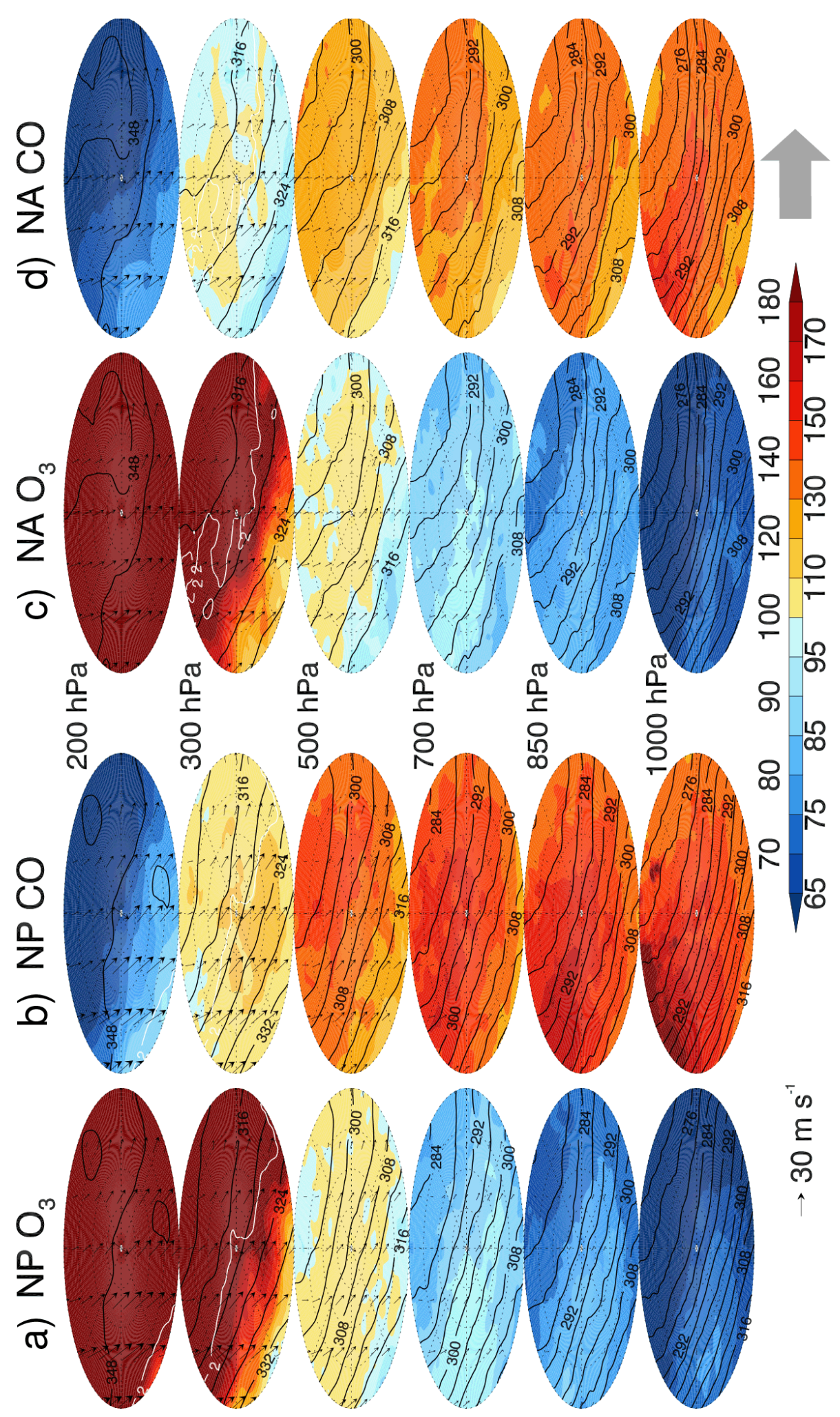

Figure 5. Same as Fig. 4 but for storm tracks with the background meteorology and chemistry. 

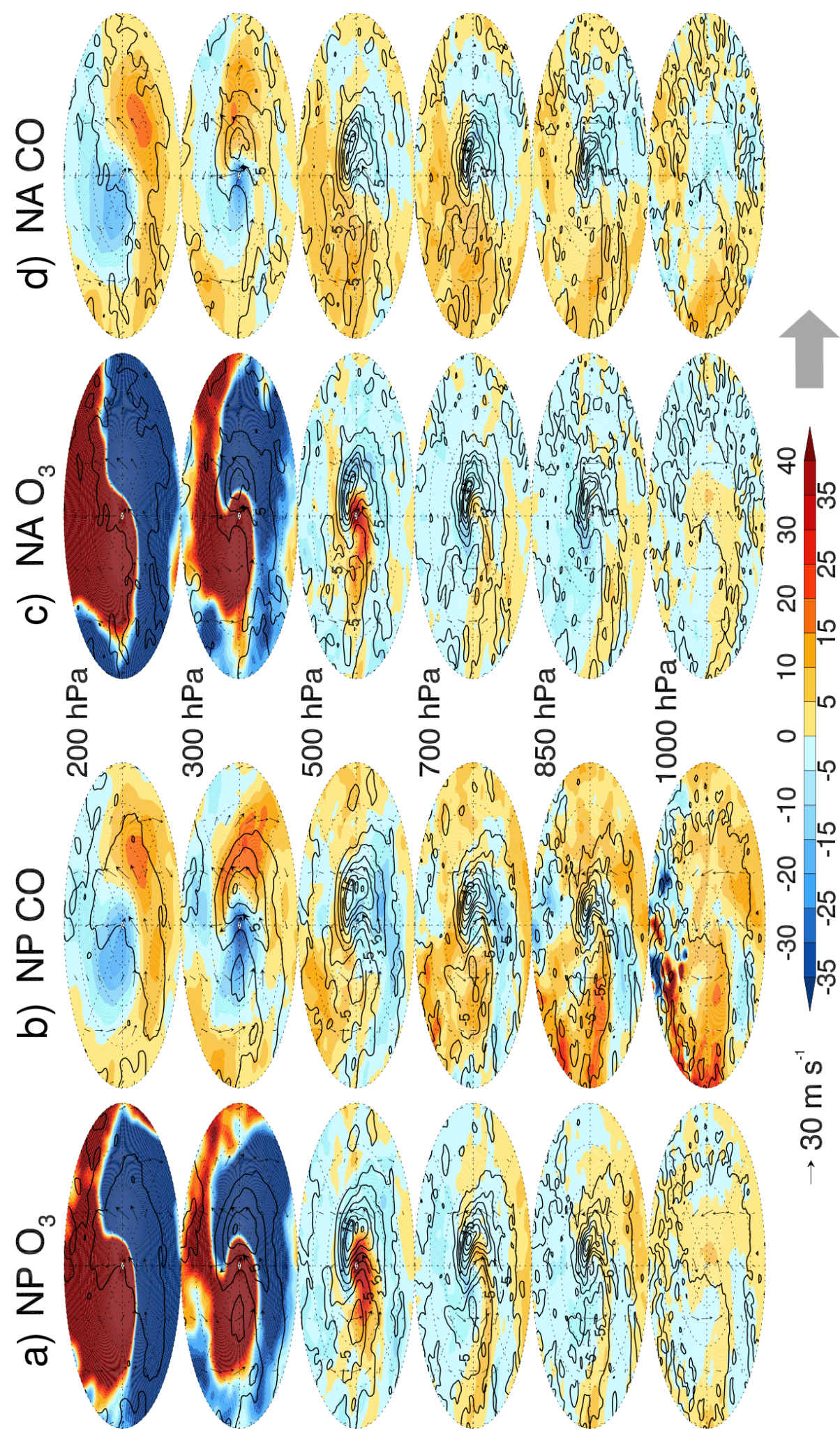

Figure 6. (a, c) $\mathrm{O}_{3}$ and (b, d) CO anomalies (ppb) of the (a, b) NP and (c, d) NA storm-centered composite (Fig. 4) minus the background composite (Fig. 5) with $\omega$ storm-centered minus background anomalies (black contour lines; $4 \mathrm{hPah}^{-1}$ contour intervals). 


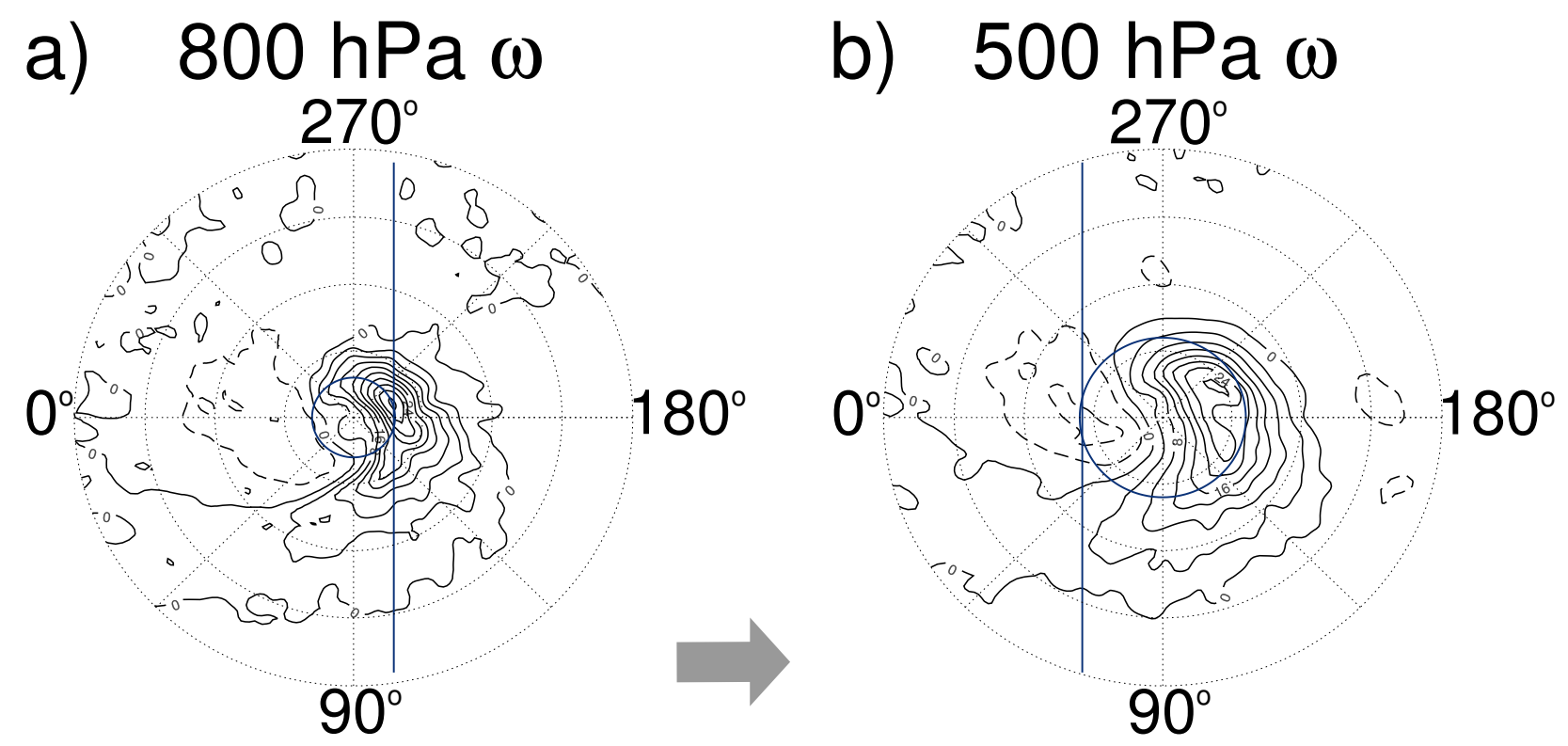

Figure 7. 95th percentile MAM storm tracks for the NP region during 2003-2012: (a) storm-centered composite $800 \mathrm{hPa} \omega(4 \mathrm{hPah}-1$ contour intervals, with positive values (solid lines) indicating ascent and negative values (dashed lines) indicating descent) with the blue line showing the location of the transect taken $3^{\circ}$ to the right of storm center to capture the WCB for Figs. 8 and 11 and the blue circle taken at $3^{\circ}$ radius around the storm center for Fig. 9; and (b) storm-centered composite $500 \mathrm{hPa} \omega\left(4 \mathrm{hPah}^{-1}\right.$ contour intervals) with the blue line showing the location of the transect taken $6^{\circ}$ to the left of the storm center to investigate the DI in Figs. 12 and 13 and the blue circle taken at $6^{\circ}$ radius around the storm center for Fig. 10. Storm propagation is toward the right as indicated by the large grey arrow. Radial dotted lines are plotted every $45^{\circ}$, and dotted circles represent $5,10,15$, and $20^{\circ}$ radii from storm center.

east of the NA storm center, again where the gradient of $\theta_{\mathrm{e}}$ is the greatest. The warm sector of the storm can be identified by the large values of $\theta_{\mathrm{e}}\left(\theta_{\mathrm{e}}>300 \mathrm{~K}\right.$ at $\left.1000 \mathrm{hPa}\right)$ located south of the storm center, between the cold and warm fronts. The frontal boundaries can be seen up to $500 \mathrm{hPa}$, but at the upper levels the gradient of $\theta_{\mathrm{e}}$ is affected by the jet stream and the lower stratosphere. In contrast, the gradient of $\theta_{\mathrm{e}}$ in the background composites (Fig. 5) is uniform with values higher toward the south (warm and moist) and lower towards the north (cold and dry).

The NP storm-centered composites of $\mathrm{O}_{3}$ and $\mathrm{CO}$ have similar horizontal patterns to the NA storm-centered composites, although $\mathrm{CO}$ values in NP are greater than in NA throughout most of the troposphere (Fig. 4). The same can be said for the background composites (Fig. 5). The dynamical tropopause outlined in white shows that the high $\mathrm{O}_{3}$ and low $\mathrm{CO}$ values clearly depict air in the stratosphere (Figs. 4 and 5). The impact of the storm on the meteorological and chemical variables is clear when the distribution of $\mathrm{O}_{3}$ and $\mathrm{CO}$ of Figs. 4 and 5 are compared in Fig. 6. In Fig. 6, the $\omega$ anomaly can be used to indicate the location of the ascent (here, positive $\omega$ indicates ascent) east of the storm center associated with the WCB, and the DI can be identified in the region of descent west of the storm center. A summary of aavg- $\mathrm{O}_{3}$ and aavg-CO anomalies between storm-centered and background composites at the time of maximum $\zeta_{850}$ comparable to Fig. 6 is shown in Table 1. Two different radii are used to highlight the effects the storm has close to the center $\left(6^{\circ}\right)$ relative to the mean field $\left(20^{\circ}\right)$.

At upper levels (200 and $300 \mathrm{hPa}$ ), the storm-centered composites (Fig. 4) and background composites (Fig. 5) depict air of mainly stratospheric origin with high $\mathrm{O}_{3}$ and low $\mathrm{CO}$ (no emission sources) to the north of the dynamical tropopause (white line, Figs. 4 and 5). The large differences in $\mathrm{O}_{3}$ and $\mathrm{CO}$ between the two composites are seen in Fig. 6 and Table 1. At $300 \mathrm{hPa}$, close to the storm center $\left(6^{\circ}\right.$ radii), the storm-centered aavg- $\mathrm{O}_{3}$ increases by 50 $(104.0 \mathrm{ppb})$ and $36 \%(80.3 \mathrm{ppb})$ relative to the background composite for the NP and NA regions, respectively (Table 1). Considerably higher values of $\mathrm{O}_{3}$ are found at the center of the storm at upper levels down to $500 \mathrm{hPa}$ (Fig. 6a and c). At $500 \mathrm{hPa}$, the positive $\mathrm{O}_{3}$ anomaly appears to wrap around the storm center, eastward of the negative $\omega$ anomaly, and is likely due to horizontal advection of the $\mathrm{O}_{3}$ behind the midlevel front (Fig. 6a and c). At this level, there is still a strong signal of descent of $\mathrm{O}_{3}$-rich air; the storm-centered aavg$\mathrm{O}_{3}$ within a $6^{\circ}$ spherical cap increased by $11(11.3 \mathrm{ppb})$ and $7.6 \%(7.9 \mathrm{ppb})$ relative to the background composite for NP and NA, respectively (Table 1). The largest aavg-CO differences between the storm-centered and background composites are found at $200 \mathrm{hPa}$ with decreases of $17(-11.3 \mathrm{ppb})$ and $11 \%(-7.5 \mathrm{ppb})$ for the NP and NA, respectively (Table 1). In Fig. $6 \mathrm{~b}$ and d, the upper-level (200 and $300 \mathrm{hPa})$ positive anomaly of $\mathrm{CO}$ (maximum of 25 and $20 \mathrm{ppb}$ for NP 
Table 1. Anomalies of aavg- $\mathrm{O}_{3}$ (top; ppb) and aavg-CO (bottom; ppb) of storm-centered composite minus background composite at different radii: 6 and $20^{\circ}$. Percent difference relative to the background composite is given in the parentheses.

\begin{tabular}{|c|c|c|c|c|}
\hline & \multicolumn{4}{|c|}{$\mathrm{O}_{3}$ anomalies } \\
\hline & $\mathrm{NP} 6^{\circ}$ & NA $6^{\circ}$ & NP $20^{\circ}$ & NA $20^{\circ}$ \\
\hline $200 \mathrm{hPa}$ & $135.3(21 \%)$ & $108.7(17 \%)$ & $-12.6(-2.1 \%)$ & $-1.8(-0.3 \%)$ \\
\hline $300 \mathrm{hPa}$ & $104.0(50 \%)$ & $80.3(36 \%)$ & $-3.9(-1.8 \%)$ & $0.3(0.1 \%)$ \\
\hline $500 \mathrm{hPa}$ & $11.3(11 \%)$ & $7.9(7.6 \%)$ & $-0.8(-0.8 \%)$ & $-1.1(-1.1 \%)$ \\
\hline $700 \mathrm{hPa}$ & $-2.0(-2.2 \%)$ & $-4.5(-5.0 \%)$ & $-0.8(-0.9 \%)$ & $-1.6(-1.8 \%)$ \\
\hline $850 \mathrm{hPa}$ & $-2.2(-2.8 \%)$ & $-5.5(-6.9 \%)$ & $-0.5(-0.7 \%)$ & $-2.2(-2.8 \%)$ \\
\hline \multirow[t]{3}{*}{$1000 \mathrm{hPa}$} & $2.3(3.5 \%)$ & $1.2(1.8 \%)$ & $0.5(0.7 \%)$ & $-0.9(-1.3 \%)$ \\
\hline & \multicolumn{4}{|c|}{$\mathrm{CO}$ anomalies } \\
\hline & NP $6^{\circ}$ & NA $6^{\circ}$ & NP $20^{\circ}$ & NA $20^{\circ}$ \\
\hline $200 \mathrm{hPa}$ & $-11.3(-17 \%)$ & $-7.5(-11 \%)$ & $0.4(0.6 \%)$ & $0.6(0.9 \%)$ \\
\hline $300 \mathrm{hPa}$ & $-13.0(-12 \%)$ & $-5.6(-5.5 \%)$ & $0.8(0.7 \%)$ & $0.9(0.9 \%)$ \\
\hline $500 \mathrm{hPa}$ & $-3.4(-2.4 \%)$ & $-0.0(-0.0 \%)$ & $-0.3(-0.2 \%)$ & $2.4(2.0 \%)$ \\
\hline $700 \mathrm{hPa}$ & $0.8(0.5 \%)$ & $-0.5(-0.4 \%)$ & $2.3(1.6 \%)$ & $2.4(1.8 \%)$ \\
\hline $850 \mathrm{hPa}$ & $1.6(1.1 \%)$ & $-2.3(-1.6 \%)$ & $3.8(2.6 \%)$ & $1.7(1.3 \%)$ \\
\hline $1000 \mathrm{hPa}$ & $5.0(3.3 \%)$ & $-3.8(-2.7 \%)$ & $4.5(3.0 \%)$ & $1.1(0.8 \%)$ \\
\hline
\end{tabular}

and NA, respectively) is to the east of the storm center at the exit region of the WCB. Instead of being advected around the storm center, as is seen at lower levels, the positive $\mathrm{CO}$ anomalies at upper levels can be seen to spread to the east with the westerly flow of the jet (Fig. $6 \mathrm{~b}$ and d).

In the low to mid-troposphere $(850$ to $500 \mathrm{hPa})$, there is a negative anomaly in both the $\mathrm{O}_{3}$ and $\mathrm{CO}$ in the region of maximum positive $\omega$ anomaly east of the storm for both NP and NA (Fig. 6). The negative $\mathrm{O}_{3}$ anomaly (Fig. 6a and c) is likely a result of the $\mathrm{O}_{3}$ in the warm sector at low levels that is lofted in the WCB. However, the negative CO anomaly in Fig. $6 \mathrm{~b}$ and $\mathrm{d}$ is more perplexing and is discussed below. The positive $\mathrm{CO}$ anomaly in the mid-troposphere, which would be expected from the lofting of CO-rich air in the WCB, is located to the north of the maximum ascent. This positive $\mathrm{CO}$ anomaly likely reflects the cyclonic advection around the storm center due to the system-relative winds.

In the lower part of the troposphere $(1000$ to $700 \mathrm{hPa})$, the relatively higher $\mathrm{O}_{3}$ remains behind the cold front, which can be identified in Fig. $6 \mathrm{a}$ and $\mathrm{c}$ by the band of $0-10 \mathrm{ppb}$ positive anomalies to the southwest of the storm center at those heights. At $1000 \mathrm{hPa}$, the storm-centered aavg- $\mathrm{O}_{3}$ within a $6^{\circ}$ spherical cap increased slightly $(\sim 4 \%)$ relative to the background composite for NP and NA, while at 850 and $700 \mathrm{hPa}$, the storm-centered aavg- $\mathrm{O}_{3}$ within a $6^{\circ}$ spherical cap decreased by $\sim 7 \%$ (Table 1). In Fig. 6, there is positive $\mathrm{O}_{3}$ at $1000 \mathrm{hPa}$ over a larger area at the storm center than at 850 and $700 \mathrm{hPa}$. This is likely due to negligible vertical velocity at this low level, which is present at 850 and $700 \mathrm{hPa}$ above this region of positive $\mathrm{O}_{3}$ at $1000 \mathrm{hPa}$ at the storm center. The $\mathrm{CO}$ in both composites (Figs. $4 \mathrm{~b}$ and d, $5 \mathrm{~b}$ and d) between 1000 and $700 \mathrm{hPa}$ is greatest far west of the center closer to the emission sources. However, in the background composites there is no cold front to enforce a boundary on the high $\mathrm{CO}$, resulting in a negative $\mathrm{CO}$ anomaly in the warm sector and the region of positive $\omega$ anomalies in Fig. $6 \mathrm{~b}$ and d. Close to the storm center ( $6^{\circ}$ spherical cap), in the lower part of the troposphere (1000 to $700 \mathrm{hPa}$ ), the storm-centered composite aavg-CO increases by $\sim 3.5 \%$ for NP and decreases by $\sim 3 \%$ for NA relative to the background composites (see Table 1).

To summarize, Fig. 6 and Table 1 show the effect of storms on the vertical and horizontal transport of $\mathrm{O}_{3}$ and $\mathrm{CO} . \mathrm{O}_{3}$-rich and $\mathrm{CO}$-poor stratospheric air increases $\mathrm{O}_{3}$ and decreases $\mathrm{CO}$ close to the storm center down to $500 \mathrm{hPa}$ (Fig. 6). Comparing the aavg- $\mathrm{O}_{3}$ and aavg-CO for the different radii in Table 1 at upper levels $(200$ to $500 \mathrm{hPa})$, the large differences in anomalies between the $6^{\circ}$ cap close to the storm center and the full $20^{\circ}$ cap indicate the large effects of the storm close to the storm center. Between 1000 and $500 \mathrm{hPa}$, positive $\mathrm{O}_{3}$ anomalies reach the surface as part of the DI; however, $\mathrm{CO}$ levels are too high behind the cold front for the same signal to be seen (Fig. 6). The WCB, the region of ascent east of the storm center, lofts CO-rich and $\mathrm{O}_{3}$-poor air from low levels to upper levels which is advected around the storm at mid-levels and downstream at upper levels (Fig. 6).

\subsection{Airstream analysis}

In order to better understand the flow of air within the storm and to relate this to the chemical species distribution, vertical cross sections were taken through the composites along transects representing the WCB and DI (Catto et al., 2010; Dacre et al., 2012; Dacre and Gray, 2013). To capture the WCB, 

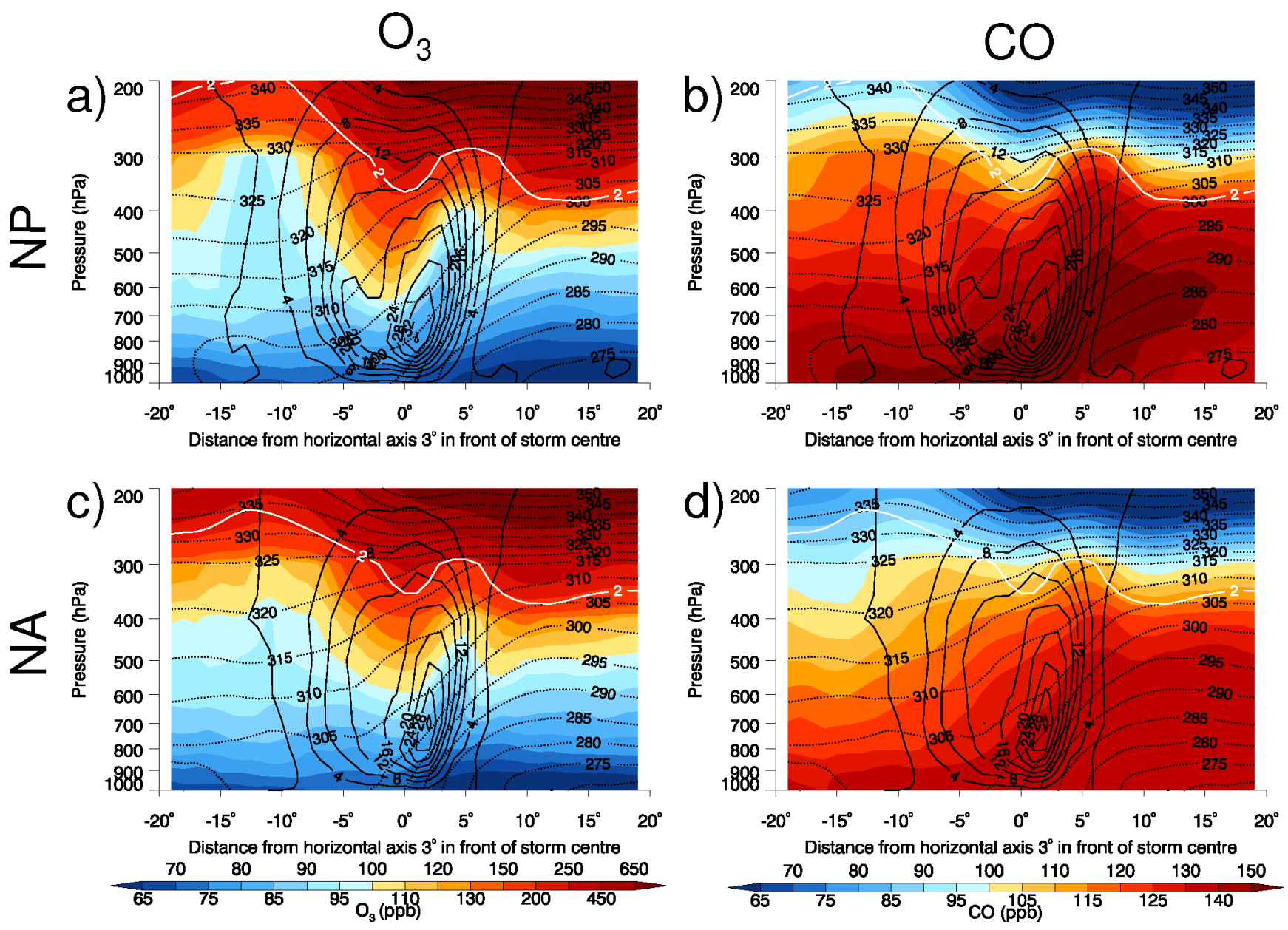

Figure 8. Vertical cross sections of the storm-centered composite for (a, b) NP and (c, d) NA 95th percentile MAM storm tracks during 2003-2012 for the WCB, $3^{\circ}$ to the right of storm center. (a, c) $\mathrm{O}_{3}$ and (b, d) $\mathrm{CO}$ (ppb) with $\theta_{\mathrm{e}}$ (dotted contour lines, $5 \mathrm{~K}$ intervals), $\omega$ (solid contour lines; $4 \mathrm{hPah}^{-1}$ contour intervals, with positive values indicating ascent), and the isosurface of 2 PVU (solid white line) are shown.

a vertical cross section through the point of maximum ascent, located $3^{\circ}$ east of the storm, was taken (blue line, Fig. 7a). Similarly, the DI was identified by the region of maximum descent behind the storm, located $6^{\circ}$ behind the storm (blue line, Fig. 7b). The WCB and DI have been further pinpointed on these vertical cross sections (Figs. 8 and 12, respectively), by the location of maximum ascent for the WCB and maximum descent for the DI, along the steepest $\theta_{\mathrm{e}}$ slope (Catto et al., 2010). The cross sections are $\sim 40^{\circ}$ diameter with positive axis values to the north. Figures 9 and 10 are vertical cylindrical cross sections at different radial distances ( 3 and $6^{\circ}$, blue circles, Fig. 7a and b, respectively) from the center of the storm composites that capture the effects of the cyclonic flow around the storm center with the different airstreams. Figure 9 is centered on $180^{\circ}$ (see Fig. 7a for orientation) to focus on ascent in WCB. Figure 10 is centered on $0^{\circ}$ (see Fig. 7b) to focus on descent in DI.

\subsubsection{Warm conveyor belt}

In Fig. 8, the WCB is located between 0 and $5^{\circ}$, where maximum ascent (positive $\omega$ ) is located in the region of steep $\theta_{\mathrm{e}}$. In the WCB, $\mathrm{O}_{3}$-poor and $\mathrm{CO}$-rich air is advected upwards isentropically (along $\theta_{\mathrm{e}}$ contours), with $\mathrm{CO}$ following the $\theta_{\mathrm{e}}$ contours more closely than $\mathrm{O}_{3}$ (Fig. 8). Outside the WCB, high values of $\mathrm{O}_{3}$ are found at upper levels and at the storm center, the spatial patterns of which closely aligned with the dynamical tropopause delineation, including the dip of the tropopause at the storm center which may induce stratosphere-troposphere exchange. $\mathrm{O}_{3}$-poor air reaches $300 \mathrm{hPa}$ south of the storm center (between -20 and $\left.-5^{\circ}\right)$. However, in this transect it does not appear to have risen isentropically (Fig. $8 \mathrm{a}$ and c).

Close to the storm center ( $3^{\circ}$ radius, Fig. 9 ), ascent dominates the eastern half $\left(90\right.$ to $\left.270^{\circ}\right)$ of the storm-centered composites, with maximum ascent $\left(>35 \mathrm{hPah}^{-1}\right.$ for $\mathrm{NP}$ and $>30 \mathrm{hPah}^{-1}$ for NA) to the northeast of the storm center be- 

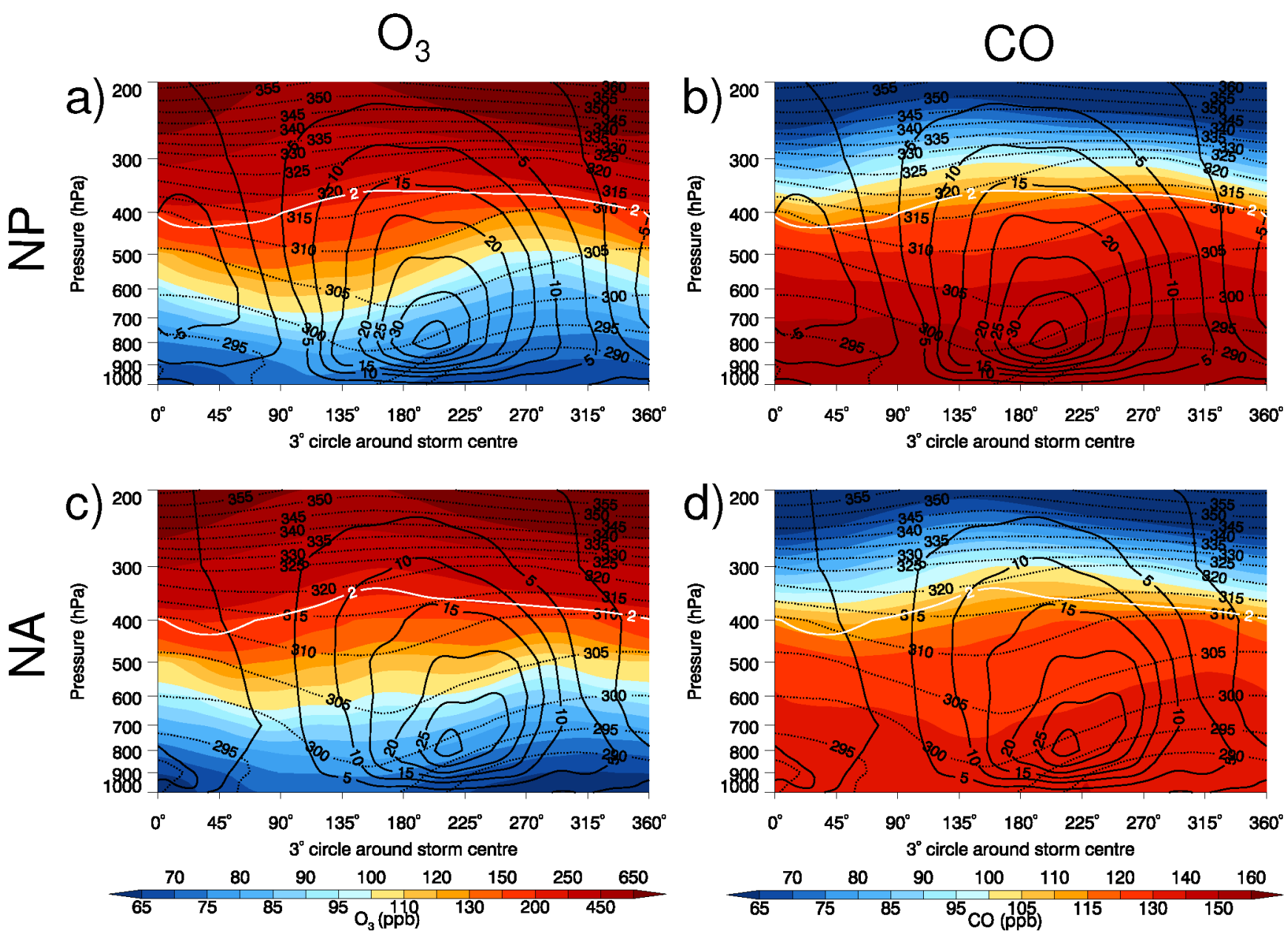

Figure 9. Vertical cylinders at $3^{\circ}$ radius for the storm-centered composite for (a, b) NP and (c, d) NA 95th percentile MAM storm tracks during 2003-2012. (a, c) $\mathrm{O}_{3}$ and (b, d) $\mathrm{CO}$ (ppb), with $\theta_{\mathrm{e}}$ (dotted contour lines, $5 \mathrm{~K}$ intervals), $\omega$ (solid contour lines; $5 \mathrm{hPah}{ }^{-1}$ contour $^{-2}$ intervals, with positive values indicating ascent), and the isosurface of 2 PVU (solid white line) are shown.

tween 180 and $225^{\circ}$ and between 700 and $850 \mathrm{hPa}$. Between 180 and $270^{\circ}$ (to the northeast of the storm center), $\mathrm{O}_{3}$ and $\mathrm{CO}$ ascend isentropically in the WCB from 1000 to $400 \mathrm{hPa}$ for NP (Fig. 9a and b) and to $500 \mathrm{hPa}$ for NA (Fig. 9c and d). The high $\mathrm{O}_{3}(>100 \mathrm{ppb})$ at the storm center between 400 and $600 \mathrm{hPa}$ in Fig. $8 \mathrm{a}$ and $\mathrm{c}$ is captured in Fig. 9 from 135 to $225^{\circ}$, where $\mathrm{O}_{3}$-rich air has descended (negative $\omega$ ) between 0 and $45^{\circ}$ (Fig. 9) and has been advected eastward around the storm center (see $500 \mathrm{hPa}$ level, Fig. $4 \mathrm{a}$ and c).

Further from the storm center, the $6^{\circ}$ radius vertical cylindrical cross section (Fig. 10) captures the periphery of the ascent at low levels but passes through the maximum ascent at upper levels. The maximum ascent is weaker $\left(<25 \mathrm{hPah}^{-1}\right.$ for both regions) than in Fig. 9 at $3^{\circ}$ from the storm center. The region of ascent is larger for NP (Fig. 10a and b) than for $\mathrm{NA}$ (Fig. 10c and d). $\mathrm{O}_{3}$ and $\mathrm{CO}$ ascend isentropically in the mid-troposphere in the regions of maximum ascent between roughly 135 and $270^{\circ}$ (Fig. 10).
Figure 11 illustrates the differences in $\mathrm{O}_{3}, \mathrm{CO}$, and $\omega$ between the storm-centered composites (Fig. 8) and the background composites in the WCB transect (blue line, Fig. 7a). The $\omega$ anomaly is greater in the NP storms (Fig. 11a and b) than NA storms (Fig. 11c and d). The $\mathrm{O}_{3}$-poor air that ascended in the WCB (between 0 to $5^{\circ}$, Fig. $8 \mathrm{a}$ and c) reduces the $\mathrm{O}_{3}$ relative to the background composite with maximum negative anomaly of more than 40 and $20 \mathrm{ppb}$ for NP and NA regions, respectively, at $\sim 300 \mathrm{hPa}$ and $5^{\circ}$ north of the storm center at the end of the WCB (Fig. 11a and c). At the storm center, $\mathrm{O}_{3}$ increases to over 80 and $40 \mathrm{ppb}$ in the NP and NA regions (Fig. 11a and c), respectively, relative to the background composite down to $400 \mathrm{hPa}$ and small positive anomalies extend to the surface in the NP and near the surface in the NA regions. There is a positive $\mathrm{CO}$ anomaly (15 to $18 \mathrm{ppb}$ ) in the WCB and a negative $\mathrm{CO}$ anomaly (21 to $24 \mathrm{ppb}$ ) in the storm center for the NP (Fig. 11b), that mirror the location of the negative and positive $\mathrm{O}_{3}$ anomalies of Fig. 11a, again showing the influence of the WCB. As ex- 

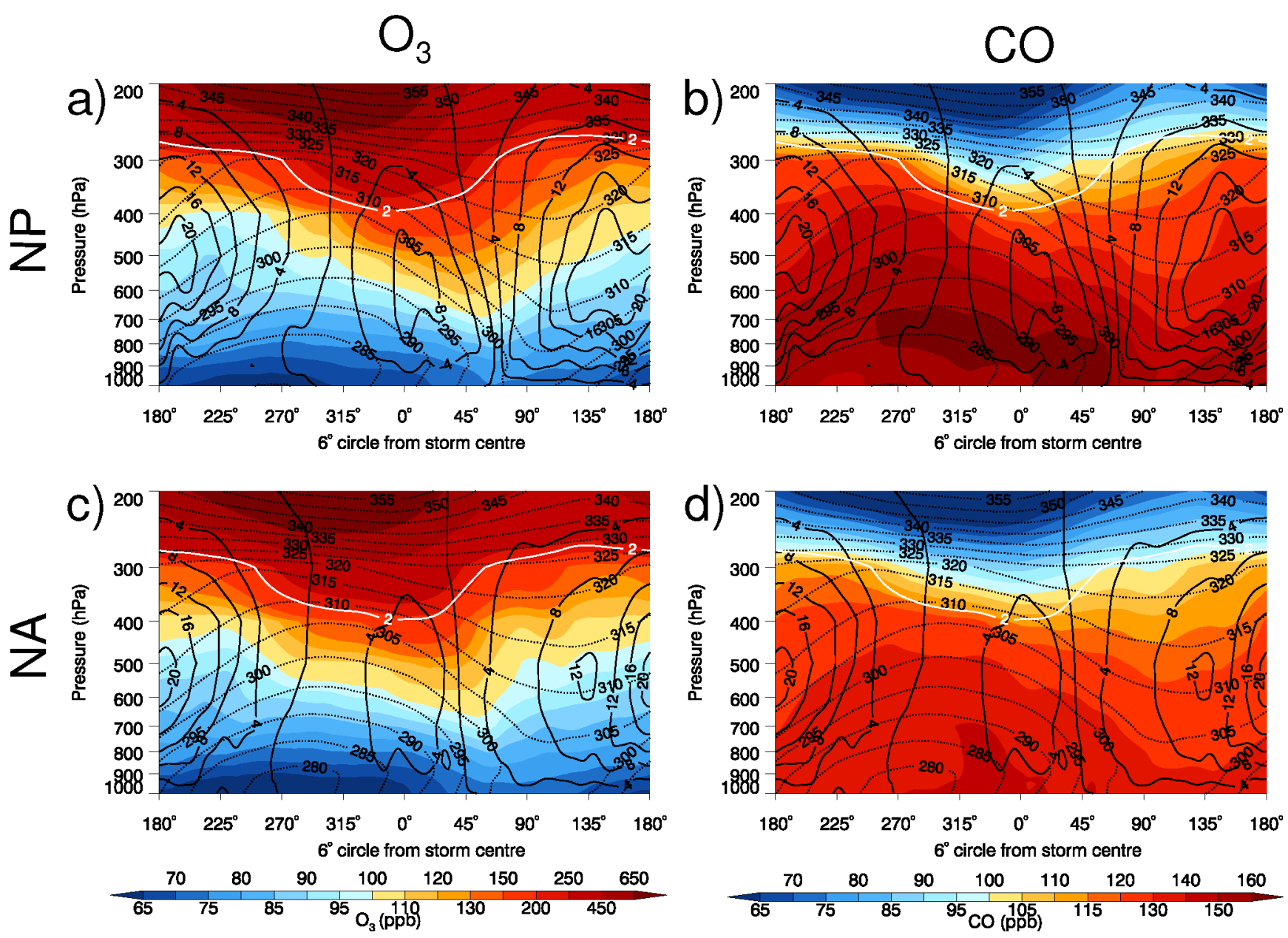

Figure 10. Vertical cylinders at $6^{\circ}$ radius for horizontal composite for (a, b) NP and (c, d) NA 95th percentile MAM storm tracks during

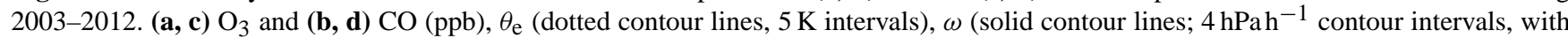
positive values indicating ascent), and the isosurface of 2 PVU (solid white line) are shown.

pected, the $\mathrm{CO}$ anomalies for the NA region (Fig. 11d) are smaller than the NP storm-centered composite relative to the background composite.

\subsubsection{Dry intrusion}

In Fig. 12, the DI is located between -5 and $5^{\circ}$, where maximum descent (negative $\omega$ ) is located in the region of steep $\theta_{\mathrm{e}}$. There is greater descent in the NP storm-centered composites (up to $-8 \mathrm{hPah}^{-1}$ ) than in the NA storm-centered composites (up to $-4 \mathrm{hPah}^{-1}$ ). The effect of the DI on the distribution of $\mathrm{O}_{3}$ and $\mathrm{CO}$ can be seen through most of the troposphere in Fig. 12. $\mathrm{O}_{3}$-rich air from the stratosphere descends in the DI to $\sim 400 \mathrm{hPa}$ (Fig. 12a and c), with $\mathrm{O}_{3}$-rich air reaching the surface (NP) or near the surface (NA) between -10 and $-5^{\circ}$ (as seen in Figs. 4a and c, 6a and c behind the surface cold front). CO-poor air also descends isentropically in the DI at upper levels, but it does not appear to descend into the lower troposphere as it is diluted in the CO-rich air of the mid- to lower troposphere.

Figure 10 displays $\mathrm{O}_{3}$ and $\mathrm{CO}$ concentrations at a $6^{\circ}$ radius around the storm center, highlighting the DI, with maximum descent between 315 and $45^{\circ}$ in both regions. $\mathrm{O}_{3}$-rich air between 270 and $90^{\circ}$ descends isentropically between 500 and $700 \mathrm{hPa}$ (Fig. 10a and c). Above $500 \mathrm{hPa}$, the stratospheric air has descended in alignment with the tropopause pattern but does not follow the isentropes (Fig. 10a and c); instead, it has likely been advected around the storm center by the upper-level jet (see Fig. 4a and c). CO-poor air descends isentropically in the DI between 300 and $700 \mathrm{hPa}$ and 270 and $10^{\circ}$ in the NP storm-centered composite (Fig. 10b) and over a larger area between 300 and $700 \mathrm{hPa}$ and 270 and $90^{\circ}$ in the NA storm-centered composites (Fig. 10d).

Figure 13 illustrates the differences in $\mathrm{O}_{3}, \mathrm{CO}$, and $\omega$ between the storm-centered composites (Fig. 12) and the background composites in the DI transect (blue line, Fig. 7b). The negative $\omega$ anomaly is greater in the NP storms (Fig. 13a and 

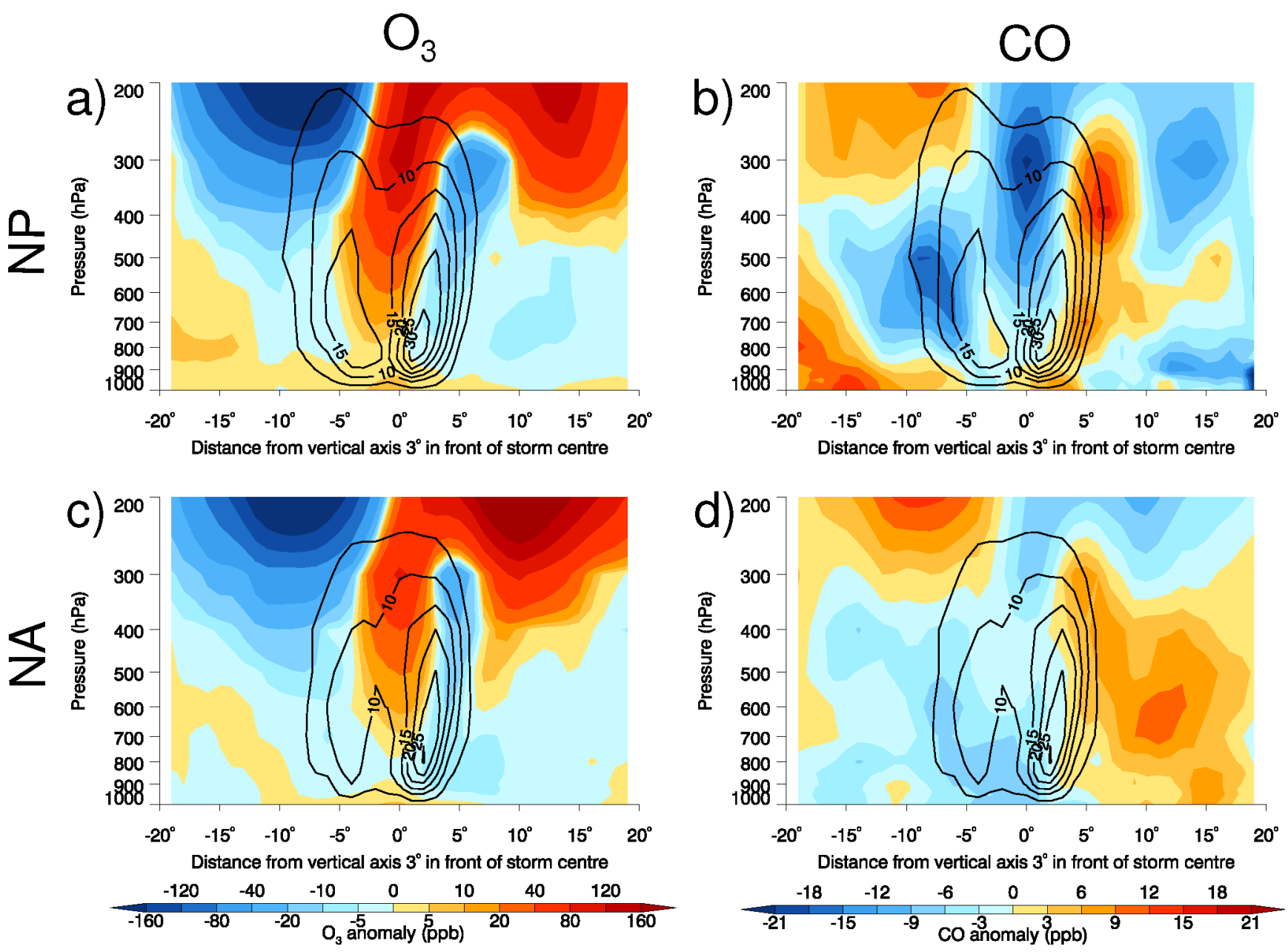

Figure 11. (a, c) $\mathrm{O}_{3}$ and (b, d) $\mathrm{CO}$ anomalies (ppb) for WCB for storm-centered composites (Fig. 8) minus background composites for the 95th percentile MAM storm tracks during 2003-2012 for (a, b) NP and (c, d) NA. Solid contours are $\omega$ anomalies (5 hPah ${ }^{-1}$ contour intervals).

b) than NA storms (Fig. 13c and d). The positive $\mathrm{O}_{3}$ anomaly structures are very similar in both NP and NA (Fig. 13a and c) in which large positive $\mathrm{O}_{3}$ anomalies are found at the storm center in the upper troposphere: $>40 \mathrm{ppb}$ at $400 \mathrm{hPa}$ and $>20 \mathrm{ppb}$ at $500 \mathrm{hPa}$ in both regions. Small positive $\mathrm{O}_{3}$ anomalies (less than $5 \mathrm{ppb}$ ) reach down to the surface in both regions between -10 and $-5^{\circ}$, south of the storm center, behind the cold front as seen in Fig. 6a and c. Negative CO anomalies in the DI reach from the lower stratosphere to $\sim 500 \mathrm{hPa}$ for the NP storms (Fig. 13b) and $\sim 400 \mathrm{hPa}$ for the NA storms (Fig. 13d). Unlike the $\mathrm{O}_{3}$ anomalies, the negative $\mathrm{CO}$ anomalies do not extend lower than the mid-troposphere (Fig. 13b and d). Instead, in Figs. $6 \mathrm{~b}$ and $\mathrm{d}$ and $13 \mathrm{~b}$ and d, there are positive $\mathrm{CO}$ anomalies of up to $15 \mathrm{ppb}$ in the NP and $9 \mathrm{ppb}$ in the NA in the region behind the cold front $(-10$ to $-5^{\circ}$ ) which likely removed the DI signal in the CO distribution in the mid- to low troposphere.

To conclude, the airstream analysis has successfully captured the vertical airflow within the intense springtime storms and highlights the detailed behavior with height and distance from the storm center. The rise of $\mathrm{O}_{3}$-poor and $\mathrm{CO}$-rich air in the WCB reduced $\mathrm{O}_{3}$ at $\sim 300 \mathrm{hPa}$ by more than 40 and $20 \mathrm{ppb}$ in the NP and NA regions, respectively, and increased $\mathrm{CO}$ at $\sim 400 \mathrm{hPa}$ by up to 18 and $9 \mathrm{ppb}$ in the NP and NA regions, respectively (see Fig. 11). At the storm center, the descent of $\mathrm{O}_{3}$-rich and $\mathrm{CO}$-poor air in the $\mathrm{DI}$ increased $\mathrm{O}_{3}$ by $\sim 20-40 \mathrm{ppb}$ in the mid-troposphere in both regions and decreased $\mathrm{CO}$ at $\sim 300 \mathrm{hPa}$ over $20 \mathrm{ppb}$ and up to $15 \mathrm{ppb}$ in the NP and NA regions, respectively (see Fig. 13). South of the storm center behind the cold front, the DI increased $\mathrm{O}_{3}$ down to the surface in both regions ( $<5$ ppb; Fig. 13a and c).

\section{Discussion and conclusions}

The influence of mid-latitude storm systems on springtime $\mathrm{O}_{3}$ and $\mathrm{CO}$ has been examined by investigating intense storms over the North Pacific and North Atlantic basins in 

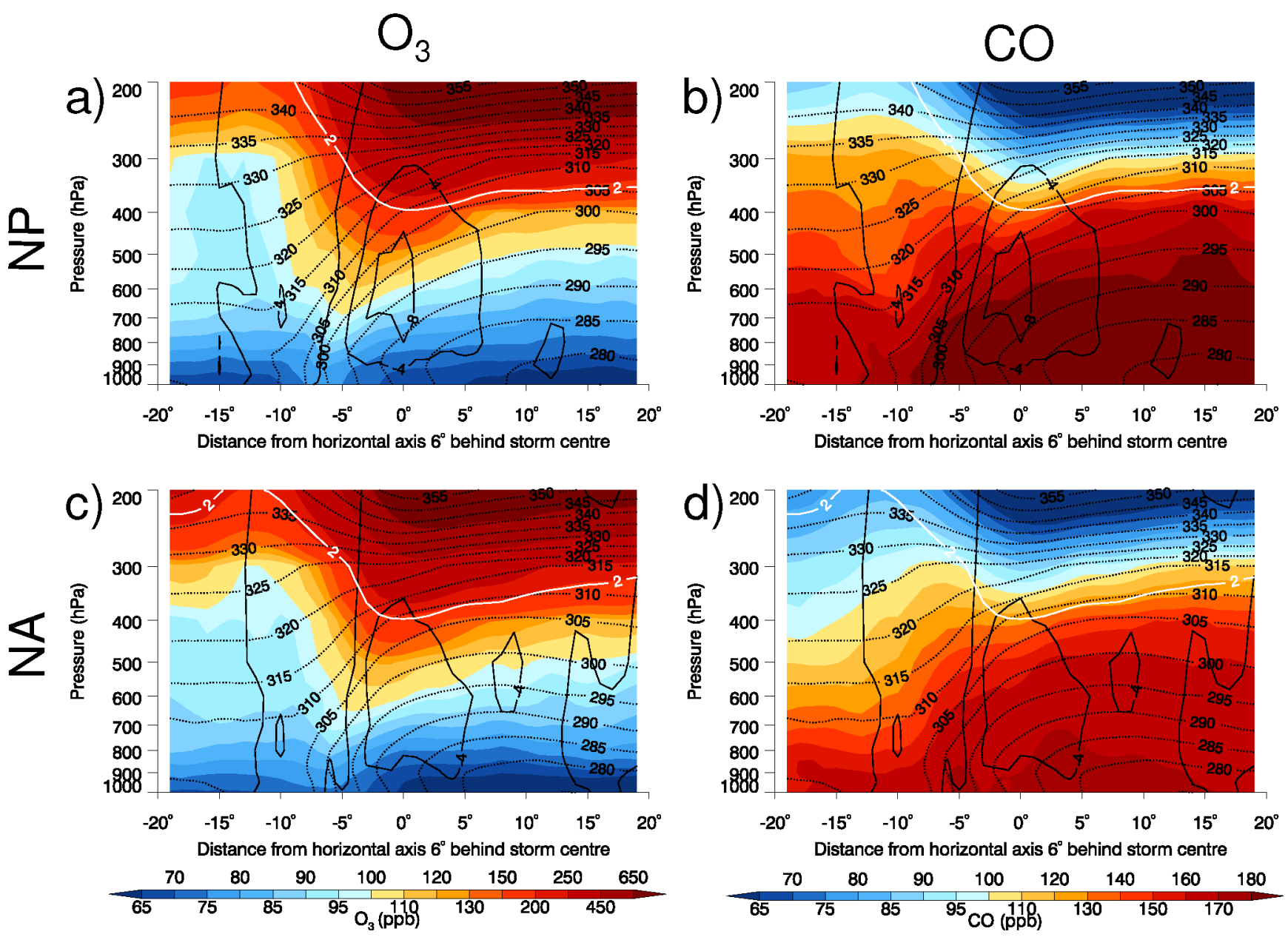

Figure 12. Vertical cross sections of the horizontal composite for (a, c) NP and (b, d) NA 95th percentile MAM storm tracks during 20032012 for the DI, $6^{\circ}$ to the left of the storm center. $(\mathbf{a}, \mathbf{c}) \mathrm{O}_{3}$ and $(\mathbf{b}, \mathbf{d}) \mathrm{CO}(\mathrm{ppb})$ with $\theta_{\mathrm{e}}$ (dotted contour lines, $5 \mathrm{~K}$ intervals), $\omega$ (solid contour lines; $4 \mathrm{hPah}^{-1}$ contour intervals, with positive values indicating ascent), and the isosurface of $2 \mathrm{PVU}$ (solid white line) are shown.

the MACC reanalysis data set for the period 2003-2012. About 60 intense storms (95th percentile) were identified in each region. The meteorological and chemical variables within a spherical cap (determined by a carefully selected radius) at each point along the storm tracks were used to create a composited storm for each region. It was found that aavg- $\mathrm{O}_{3}$ had similar structure within the composite storm's life cycles for both NP and NA regions at all levels. However, aavg-CO was greater for the NP region than the NA region at all levels, especially in the lower troposphere. This is due to the higher emissions in Asia than in North America. Using the method of Grandey et al. (2011), the background conditions for the storm track locations were identified. By comparing composition along the same storm track locations during intense storms and non-storm conditions, the effect of the storm could be clearly seen. It was found that as the storm evolved, aavg- $\mathrm{O}_{3}$ between 200 and $500 \mathrm{hPa}$ and aavg$\mathrm{CO}$ between 200 and $300 \mathrm{hPa}$ are affected more by the storm dynamics than by changes in the storm location.
Further analysis into the storm composite structure at the time of maximum $\zeta_{850}$ showed in more detail how the airstreams and frontal boundaries play a substantial role in the redistribution of $\mathrm{O}_{3}$ and $\mathrm{CO}$. Without storms present, high values of $\mathrm{O}_{3}$ are found in the stratosphere and upper troposphere and lower values of $\mathrm{O}_{3}$ are found in lower troposphere, while the opposite gradient is seen for $\mathrm{CO}$. With the storms present, a weaker gradient at mid- to upper levels is seen, which is driven by the vertical and horizontal airstream transport of pollutants. $\mathrm{CO}$ is highest near the surface due to the proximity to emission sources and is kept out of the warm sector by the cold frontal boundary. At the time of the composite storm's maximum intensity and close to the storm center, at high altitudes $(300 \mathrm{hPa})$, there is a 50 and $36 \%$ increase in $\mathrm{O}_{3}$ for NP and NA storm-centered composites relative to the background, respectively, while at the surface $(1000 \mathrm{hPa})$ there is a small yet still important increase of 3.5 and $1.8 \%$, respectively. At high altitudes $(300 \mathrm{hPa})$, there is a 12 and $5.5 \%$ decrease in CO for NP and NA storm- 

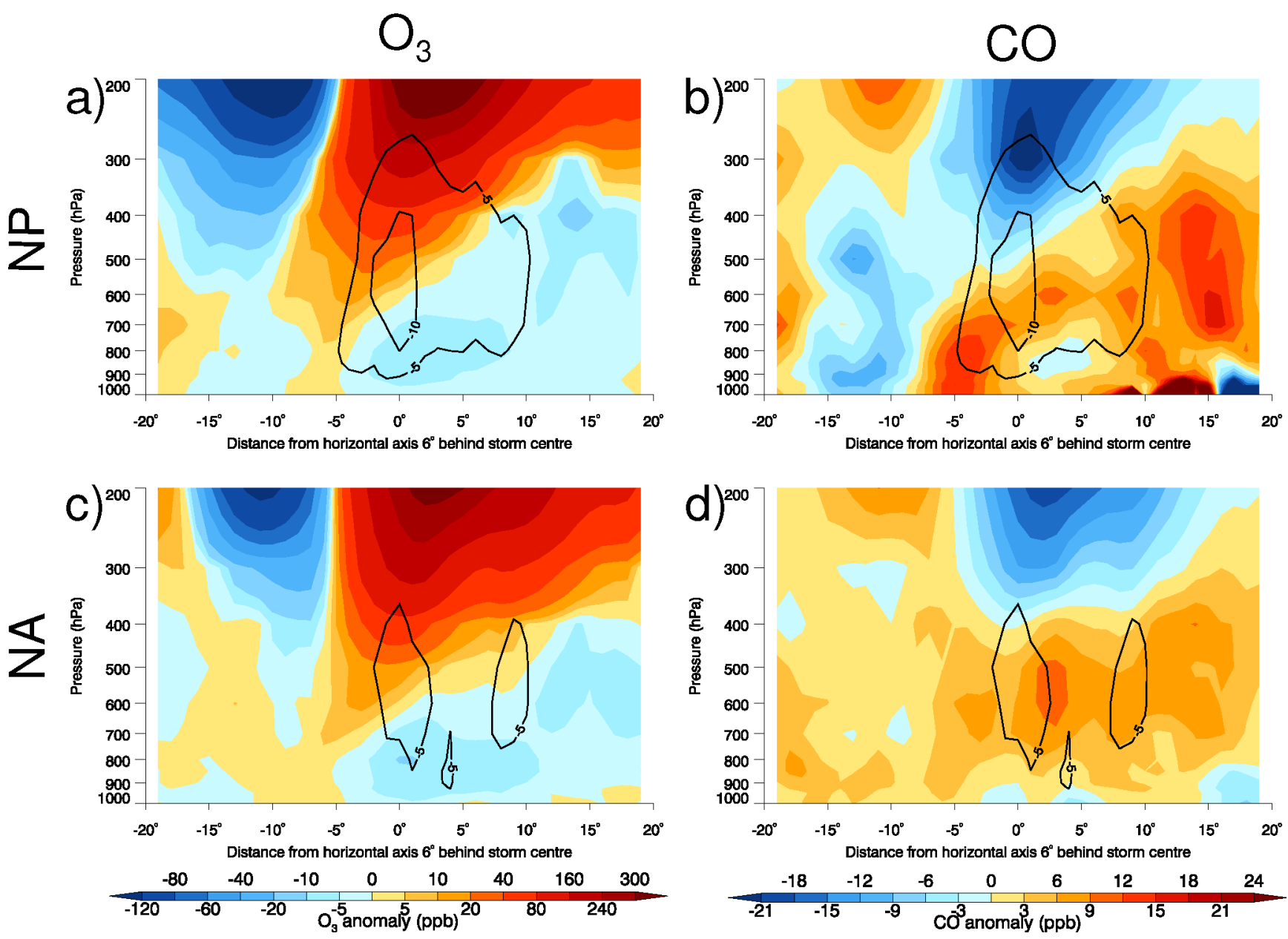

Figure 13. (a, c) $\mathrm{O}_{3}$ and (b, d) CO anomalies (ppb) for DI for storm-centered composites (Fig. 12) minus background composites for the 95th

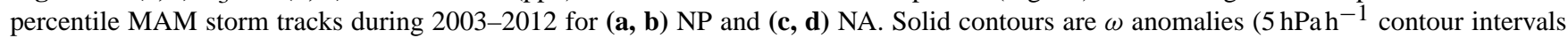
with positive values indicating ascent).

centered composites relative to the background, while at the surface $(1000 \mathrm{hPa})$ there is an increase of $3.3 \%$ in $\mathrm{CO}$ in the NP region but a decrease of $2.7 \%$ in the NA region.

Ahead of the storm, in the region of ascent along the $\mathrm{WCB}, \mathrm{O}_{3}$ and $\mathrm{CO}$ rise isentropically, advecting $\mathrm{CO}$-rich and $\mathrm{O}_{3}$-poor air from the surface $(1000 \mathrm{hPa})$ to upper levels $(\sim 300 \mathrm{hPa})$. This shows the role of the WCB lofting pollutants out of the boundary layer and into the free troposphere, where they can be transported rapidly at upper levels as the storm interacts with the jet stream.

The influence of stratospheric intrusions through DI descent has also been examined. $\mathrm{O}_{3}$-rich air has subsided in the DI behind the storm, remaining behind the cold front at the surface. In the mid-troposphere ( $\sim 500 \mathrm{hPa})$, higher values of $\mathrm{O}_{3}$ are found at the center of the storm, as the frontal boundaries at this altitude are further to the east. Hess and Zbinden (2013) also suggest that rapid mixing isentropically connects surface-ozone changes with stratospheric air which can influence the low to mid-troposphere (up to $500 \mathrm{hPa}$ ). The $5 \mathrm{ppb}$
$\mathrm{O}_{3}$ anomaly at $1000 \mathrm{hPa}$ between -10 and $-5^{\circ}$ in the region at the end of the DI (Fig. 13a and c) is consistent with the findings of Hess and Zbinden (2013), who found that 1 to $5 \mathrm{ppbv}$ of $\mathrm{O}_{3}$ at the surface has stratospheric origin. $\mathrm{CO}$ poor air descends from the stratosphere in the DI but only to the mid-troposphere. The dilution of the CO-poor air in the CO-rich air in the lower troposphere could likely remove the signal of the descent toward the surface as seen in the $\mathrm{O}_{3}$ field. Owen et al. (2006) found uplift of $\mathrm{CO}$ from North America to above $6 \mathrm{~km}$ (upper troposphere) in the WCB of one storm, which circulated around the center for 2 days before being entrained with the DI. The higher values of $\mathrm{CO}$ and lower values of $\mathrm{O}_{3}$ to the north of the storm center in the mid-troposphere ( 850 to $500 \mathrm{hPa}$ ) could be due to $\mathrm{CO}$ rich and $\mathrm{O}_{3}$-poor air advected around the storm center, after it has risen to those levels within the WCB (Cooper et al., 2004b).

Polvani and Esler (2007) used idealized tracer transport in different baroclinic life cycles to distinguish the transport 
and mixing of air masses within the troposphere and lower stratosphere in two types of cyclone development (LC1 and LC2). The WCB or DI are characterized by either anticyclonic (LC1) or cyclonic (LC2) isentropic advection. In reality, systems likely have both types of advection or transition from one type to another (Thorncroft et al., 1993; Schultz et al., 1998; Polvani and Esler, 2007). Our composites are likely a mix of both types, as we find anticyclonic advection at the end of the WCB, cyclonic motion around the storm center in both the WCB and DI in the mid-troposphere, and anticyclonic advection behind the cold front at lower levels. It may be of interest to select storms from the MACC reanalysis according to their development type to see if similar storm structures as shown in Polvani and Esler (2007) are obtained. This would likely be difficult, due to the fact cyclones may change type during their development and they may have a hybrid structure, making them difficult to associate with either of the two conceptual models.

Conceptual models of trace gas concentrations in the different airstreams have been constructed based on flight campaign data (Cooper et al., 2001, 2002a, b). As part of the North Atlantic Regional Experiment (NARE) campaign, Cooper et al. (2002a) found $\mathrm{O}_{3}$ in spring of 1996 in the WCB to decrease with increasing altitude. They found $\mathrm{CO}$ in the same season in the WCB to be greatest at low levels and lowest in the mid-troposphere. The DI was separated into the dry airstream (DA), which reaches from upper levels down to $\sim 600 \mathrm{hPa}$, and the post-cold front (PCF) located below the DA. In DA and PCF, they found $\mathrm{O}_{3}$ in spring of 1996 to decrease with decreasing altitude and they found $\mathrm{CO}$ to roughly increase with decreasing altitude, with some discrepancy between the DA and PCF. Using the MAM 2003-2012 data, we found, at the time of maximum $\zeta_{850}$, values of $\mathrm{O}_{3}$ to be higher and CO to be lower compared to Cooper et al. (2002a). With emission decreases as outlined in Sect. 1, the concentrations of $\mathrm{O}_{3}$ and $\mathrm{CO}$ in the WCB and DI are likely to have changed in the last 20 years.

This study has focused on the composite of individual intense storms. However, the movement of pollutants within a single storm cannot be considered as a closed system. Concentrations within the airstreams can be affected by pollutants that have been transported in the airstreams of upwind and downwind storms. Cooper et al. (2004a, b) used back trajectory analysis to track trace gas concentrations through the different airstreams to show how upstream and downstream storms can influence each other's composition. Cooper et al. (2004b) found that ascent occurred in the WCB, followed by rapid transport with the jet stream. The pollution became entrained and descended in the downwind decaying WCB (Cooper et al., 2004b). In addition, air descending in the DI turned anticyclonically as part of a high-pressure system and become entrained in an upwind storm (Cooper et al., 2004a). The MSLP contours for the MAM 95th percentile storms in both regions stretch towards the northeast of the storm composite (not shown), which is consistent with other composite studies of strong intense storms (Manobianco, 1989; Wang and Rogers, 2001; Catto et al., 2010). Wang and Rogers (2001) suggest this is due to close proximity of downwind parent storms. Therefore, the concentrations of $\mathrm{O}_{3}$ and $\mathrm{CO}$ in the far northeast of the storm-centered composites could be affected by a downwind storm's DI.

One limitation of the MACC reanalysis is that it does not archive the chemical tendencies or fluxes of $\mathrm{O}_{3}$ and $\mathrm{CO}$ but archives only the chemical mixing ratios of the species. Therefore, we are unable to investigate the effect of storms on photolysis rates and the chemical reactions, such as $\mathrm{O}_{3}$ production and loss, occurring within the airstreams. Nevertheless, by applying the storm tracking algorithm on the MACC reanalysis, we have been able to uniquely identify the effect of transport mechanisms on composition within a "typical" intense springtime mid-latitude storm occurring in the past 10 years.

Acknowledgements. This research has been supported by the University of Edinburgh through the Principal's Career Development Scholarship, the Edinburgh Global Research Scholarship Award, and by the School of Geosciences, University of Edinburgh. The authors thank Owen Cooper for his helpful discussion on early results. We also thank the reviewers and the editor for their suggestions, which improved this manuscript.

Edited by: F. Dentener

\section{References}

Akimoto, H.: Global air quality and pollution, Science, 302, 17161719, doi:10.1126/science.1092666, 2003.

Barkley, M.: Description of MEGAN biogenic VOC emissions in GEOS-Chem, available at: http://acmg.seas.harvard.edu/geos/ wiki_docs/emissions/megan.pdf (last access: 9 April 2014), 2010.

Bauer, M. and Del Genio, A.: Composite analysis of winter cyclones in a GCM: influence on climatological humidity, J. Climatol., 19, 1652-1672, doi:10.1175/JCLI3690.1, 2006.

Benedetti, A., Morcrette, J.-J., Boucher, O., Dethof, A., Engelen, R. J., Fisher, M., Flentje, H., Huneeus, N., Jones, L., Kaiser, J. W., Kinne, S., Mangold, A., Razinger, M., Simmons, A. J., and Suttie, M.: Aerosol analysis and forecast in the European Centre for Medium-Range Weather Forecasts Integrated Forecast System: 2. Data assimilation, J. Geophys. Res., 114, 2156-2202, doi:10.1029/2008JD011115, 2009.

Bengtsson, L., Hodges, K. I., Esch, M., Keenlyside, N., Kornblueh, L., Luo, J.-J., and Yamagata, T.: How may tropical cyclones change in a warmer climate?, Tellus A, 59, 539-561, doi:10.1111/j.1600-0870.2007.00251.x, 2007.

Bengtsson, L., Hodges, K. I., and Keenlyside, N.: Will extratropical storms intensify in a warmer climate?, J. Climatol., 22, 22762301, doi:10.1175/2008JCLI2678.1, 2009.

Browning, K.: The dry intrusion perspective of extra-tropical cyclone development, Meteorol. Appl., 4, 317-324, 1997. 
Brown-Steiner, B. and Hess, P.: Asian influence on surface ozone in the United States: A comparison of chemistry, seasonality, and transport mechanisms, J. Geophys. Res., 116, D17, doi:10.1029/2011JD015846, 2011.

Carlson, T.: Airflow through midlatitude cyclones and the comma cloud pattern, Mon. Weather Rev., 108, 1498-1509, doi:10.1175/1520-0493(1980)108<1498:ATMCAT>2.0.CO;2, 1980.

Catto, J., Shaffrey, L., and Hodges, K.: Can climate models capture the structure of extratropical cyclones?, J. Climatol., 23, 16211635, doi:10.1175/2009JCLI3318.1, 2010.

Christoudias, T., Pozzer, A., and Lelieveld, J.: Influence of the North Atlantic Oscillation on air pollution transport, Atmos. Chem. Phys., 12, 869-877, doi:10.5194/acp-12-869-2012, 2012.

Cooper, O. R., Moody, J. L., Parrish, D. D., Trainer, M., Ryerson, T. B., Holloway, J. S., Hubler, G., Fehsenfeld, F. C., Oltmans, S. J., and Evans, M. J.: Trace gas signatures of the airstreams within North Atlantic cyclones: Case studies from the North Atlantic Regional Experiment (NARE '97) aircraft intensive, J. Geophys. Res., 106, 5437-5456, doi:10.1029/2000JD900574, 2nd AGU Chapman Conference on Water Vapor in the Climate System, Potomac, Maryland, 12-15 October 1999, 2001.

Cooper, O. R., Moody, J. L., Parrish, D. D., Trainer, M., Holloway, J. S., Hübler, G., Fehsenfeld, F. C., and Stohl, A.: Trace gas composition of midlatitude cyclones over the western North Atlantic Ocean: A seasonal comparison of $\mathrm{O} 3$ and CO, J. Geophys. Res., 107, ACH2-1-ACH2-12, doi:10.1029/2001JD000902, 2002a.

Cooper, O. R., Moody, J. L., Parrish, D. D., Trainer, M., Ryerson, T. B., Holloway, J. S., Hübler, G., Fehsenfeld, F. C., and Evans, M. J.: Trace gas composition of midlatitude cyclones over the western North Atlantic Ocean: a conceptual model, J. Geophys. Res., 107, ACH1-1-ACH1-13, doi:10.1029/2001JD000901, 2002b.

Cooper, O., Forster, C., Parrish, D., Dunlea, E., Hübler, G., Fehsenfeld, F., Holloway, J., Oltmans, S., Johnson, B., Wimmers, A., and Horowitz, L.: On the life cycle of a stratospheric intrusion and its dispersion into polluted warm conveyor belts, J. Geophys. Res., 109, D23, doi:10.1029/2003JD004006, 2004a.

Cooper, O. R., Forster, C., Parrish, D., Trainer, M., Dunlea, E., Ryerson, T., Hübler, G., Fehsenfeld, F., Nicks, D., Holloway, J., de Gouw, J., Warneke, C., Roberts, J. M., Flocke, F., and Moody, J.: A case study of transpacific warm conveyor belt transport: Influence of merging airstreams on trace gas import to North America, J. Geophys. Res., 109, D23, doi:10.1029/2003JD003624, 2004b.

Cooper, O. R., Parrish, D. D., Stohl, A., Trainer, M., Nédélec, P., Thouret, V., Cammas, J. P., Oltmans, S. J., Johnson, B. J., Tarasick, D., Leblanc, T., McDermid, I. S., Jaffe, D., Gao, R., Stith, J., Ryerson, T., Aikin, K., Campos, T., Weinheimer, A., and Avery, M. A.: Increasing springtime ozone mixing ratios in the free troposphere over western North America, Nature, 463, 344-348, 2010.

Cooper, O. R., Gao, R.-S., Tarasick, D., Leblanc, T., and Sweeney, C.: Long-term ozone trends at rural ozone monitoring sites across the United States, 1990-2010, J. Geophys. Res., 117, D22, doi:10.1029/2012JD018261, 2012.

Creilson, J. K., Fishman, J., and Wozniak, A. E.: Intercontinental transport of tropospheric ozone: a study of its seasonal variability across the North Atlantic utilizing tropospheric ozone resid- uals and its relationship to the North Atlantic Oscillation, Atmos. Chem. Phys., 3, 2053-2066, doi:10.5194/acp-3-2053-2003, 2003.

Dacre, H., Hawcroft, M., Stringer, M., and Hodges, K.: An extratropical cyclone atlas: a tool for illustrating cyclone structure and evolution characteristics, B. Am. Meteorol. Soc., 93, 1497-1502, 2012.

Dacre, H. F. and Gray, S. L.: Quantifying the climatological relationship between extratropical cyclone intensity and atmospheric precursors, Geophys. Res. Lett., 40, 2322-2327, doi:10.1002/grl.50105, 2013.

Danielsen, E. F.: Stratospheric-tropospheric exchange based on radioactivity, ozone and potential vorticity, J. Atmos. Sci., 25, 502$518,1968$.

Danielsen, E. F.: Stratospheric source for unexpectedly large values of ozone measured over the Pacific Ocean during Gametag, August 1977, J. Geophys. Res., 85, 401-412, doi:10.1029/JC085iC01p00401, 1980.

Dee, D. P., Uppala, S. M., Simmons, A. J., Berrisford, P., Poli, P., Kobayashi, S., Andrae, U., Balmaseda, M. A., Balsamo, G., Bauer, P., Bechtold, P., Beljaars, A. C. M., van de Berg, L., Bidlot, J., Bormann, N., Delsol, C., Dragani, R., Fuentes, M., Geer, A. J., Haimberger, L., Healy, S. B., Hersbach, H., Hólm, E. V., Isaksen, L., Kållberg, P., Köhler, M., Matricardi, M., McNally, A. P., Monge-Sanz, B. M., Morcrette, J.-J., Park, B.-K., Peubey, C., de Rosnay, P., Tavolato, C., Thépaut, J.-N., and Vitart, F.: The ERA-Interim reanalysis: configuration and performance of the data assimilation system, Q. J. Roy. Meteor. Soc., 137, 553-597, doi:10.1002/qj.828, 2011.

Derwent, R. G., Manning, A. J., Simmonds, P. G., Spain, T. G., and O'Doherty, S.: Analysis and interpretation of 25 years of ozone observations at the Mace Head Atmospheric Research Station on the Atlantic Ocean coast of Ireland from 1987 to 2012, Atmos. Environ., 80, 361-368, doi:10.1016/j.atmosenv.2013.08.003, 2013.

Dupuy, E., Walker, K. A., Kar, J., Boone, C. D., McElroy, C. T., Bernath, P. F., Drummond, J. R., Skelton, R., McLeod, S. D., Hughes, R. C., Nowlan, C. R., Dufour, D. G., Zou, J., Nichitiu, F., Strong, K., Baron, P., Bevilacqua, R. M., Blumenstock, T., Bodeker, G. E., Borsdorff, T., Bourassa, A. E., Bovensmann, H., Boyd, I. S., Bracher, A., Brogniez, C., Burrows, J. P., Catoire, V., Ceccherini, S., Chabrillat, S., Christensen, T., Coffey, M. T., Cortesi, U., Davies, J., De Clercq, C., Degenstein, D. A., De Mazière, M., Demoulin, P., Dodion, J., Firanski, B., Fischer, H., Forbes, G., Froidevaux, L., Fussen, D., Gerard, P., GodinBeekmann, S., Goutail, F., Granville, J., Griffith, D., Haley, C. S., Hannigan, J. W., Höpfner, M., Jin, J. J., Jones, A., Jones, N. B., Jucks, K., Kagawa, A., Kasai, Y., Kerzenmacher, T. E., Kleinböhl, A., Klekociuk, A. R., Kramer, I., Küllmann, H., Kuttippurath, J., Kyrölä, E., Lambert, J.-C., Livesey, N. J., Llewellyn, E. J., Lloyd, N. D., Mahieu, E., Manney, G. L., Marshall, B. T., McConnell, J. C., McCormick, M. P., McDermid, I. S., McHugh, M., McLinden, C. A., Mellqvist, J., Mizutani, K., Murayama, Y., Murtagh, D. P., Oelhaf, H., Parrish, A., Petelina, S. V., Piccolo, C., Pommereau, J.-P., Randall, C. E., Robert, C., Roth, C., Schneider, M., Senten, C., Steck, T., Strandberg, A., Strawbridge, K. B., Sussmann, R., Swart, D. P. J., Tarasick, D. W., Taylor, J. R., Tétard, C., Thomason, L. W., Thompson, A. M., Tully, M. B., Urban, J., Vanhellemont, F., Vigouroux, C., von Clarmann, 
T., von der Gathen, P., von Savigny, C., Waters, J. W., Witte, J. C., Wolff, M., and Zawodny, J. M.: Validation of ozone measurements from the Atmospheric Chemistry Experiment (ACE), Atmos. Chem. Phys., 9, 287-343, doi:10.5194/acp-9-287-2009, 2009.

Eckhardt, S., Stohl, A., Wernli, H., James, P., Forster, C., and Spichtinger, N.: A 15-year climatology of warm conveyor belts, J. Climatol., 17, 218-237, 2004.

Engelen, R. J., Serrar, S., and Chevallier, F.: Four-dimensional data assimilation of atmospheric CO2 using AIRS observations, J. Geophys. Res., 114, D3, doi:10.1029/2008JD010739, 2009.

Flemming, J., Inness, A., Flentje, H., Huijnen, V., Moinat, P., Schultz, M. G., and Stein, O.: Coupling global chemistry transport models to ECMWF's integrated forecast system, Geosci. Model Dev., 2, 253-265, doi:10.5194/gmd-2-253-2009, 2009.

Geng, Q. and Sugi, M.: Variability of the North Atlantic cyclone activity in winter analyzed from NCEP-NCAR reanalysis data, J. Climatol., 14, 3863-3873, doi:10.1175/15200442(2001)014<3863:VOTNAC>2.0.CO;2, 2001.

Grandey, B. S., Stier, P., Wagner, T. M., Grainger, R. G., and Hodges, K. I.: The effect of extratropical cyclones on satelliteretrieved aerosol properties over ocean, Geophys. Res. Lett., 38, 13, doi:10.1029/2011GL047703, 2011.

Granier, C., Guenther, A., Lamarque, J., Mieville, A., Muller, J., Olivier, J., Orlando, J., Peters, J., Petron, G., Tyndall, G., and Wallens, S.: POET, a database of surface emissions of ozone precursors, available at: http://www.aero.jussieu.fr/projet/ ACCENT/POET.php (last access: 26 March 2015), 2005.

Granier, C., Bessagnet, B., Bond, T., D’Angiola, A., Denier van der Gon, H., Frost, G., Heil, A., Kaiser, J., Kinne, S., Klimont, Z., Kloster, S., Lamarque, J.-F., Liousse, C., Masui, T., Meleux, F., Mieville, A., Ohara, T., Raut, J.-C., Riahi, K., Schultz, M., Smith, S., Thompson, A., Aardenne, J., Werf, G., and Vuuren, D.: Evolution of anthropogenic and biomass burning emissions of air pollutants at global and regional scales during the 1980-2010 period, Climatic Change, 109, 163-190, doi:10.1007/s10584-0110154-1, 2011.

Gray, S. L.: A case study of stratosphere to troposphere transport: The role of convective transport and the sensitivity to model resolution, J. Geophys. Res., 108, D18, doi:10.1029/2002JD003317, 2003.

Guenther, A., Karl, T., Harley, P., Wiedinmyer, C., Palmer, P. I., and Geron, C.: Estimates of global terrestrial isoprene emissions using MEGAN (Model of Emissions of Gases and Aerosols from Nature), Atmos. Chem. Phys., 6, 3181-3210, doi:10.5194/acp-63181-2006, 2006.

Harrold, T. W.: Mechanisms influencing distribution of precipitation within baroclinic disturbances, Q. J. Roy. Meteor. Soc., 99, 232-251, doi:10.1002/qj.49709942003, 1973.

Hegarty, J., Mao, H., and Talbot, R.: Synoptic controls on summertime surface ozone in the northeastern United States, J. Geophys. Res., 112, D14, doi:10.1029/2006JD008170, 2007.

Hess, P. G. and Zbinden, R.: Stratospheric impact on tropospheric ozone variability and trends: 1990-2009, Atmos. Chem. Phys., 13, 649-674, doi:10.5194/acp-13-649-2013, 2013.

Hodges, K. I.: A general-method for tracking analysis and its application to meteorological data, Mon. Weather Rev., 122, 2573-2586, doi:10.1175/15200493(1994)122<2573:AGMFTA>2.0.CO;2, 1994.
Hodges, K. I.: Feature tracking on the unit-sphere, Mon. Weather Rev., 123, 3458-3465, doi:10.1175/15200493(1995)123<3458:FTOTUS>2.0.CO;2, 1995.

Hodges, K. I.: Adaptive constraints for feature tracking, Mon. Weather Rev., 127, 1362-1373, doi:10.1175/15200493(1999)127<1362:ACFFT>2.0.CO;2, 1999.

Hodges, K. I., Hoskins, B. J., Boyle, J., and Thorncroft, C.: A comparison of recent reanalysis datasets using objective feature tracking: storm tracks and tropical easterly waves, Mon. Weather Rev., 131, 2012-2037, doi:10.1175/15200493(2003)131<2012:ACORRD>2.0.CO;2, 2003.

Hollingsworth, A., Engelen, R. J., Benedetti, A., Dethof, A., Flemming, J., Kaiser, J. W., Morcrette, J.-J., Simmons, A. J., Textor, C., Boucher, O., Chevallier, F., Rayner, P., Elbern, H., Eskes, H., Granier, C., Peuch, V.-H., Rouil, L., and Schultz, M. G.: Toward a monitoring and forecasting system for atmospheric composition: the GEMS project, B. Am. Meteorol. Soc., 89, 1147-1164, 2008.

Holloway, T., Levy, H., and Kasibhatla, P.: Global distribution of carbon monoxide, J. Geophys. Res., 105, 12123-12147, doi:10.1029/1999JD901173, 2000.

Holton, J. R., Haynes, P. H., McIntyre, M. E., Douglass, A. R., Rood, R. B., and Pfister, L.: Stratosphere-troposphere exchange, Rev. Geophys., 33, 403-439, doi:10.1029/95RG02097, 1995.

Horowitz, L. W.: Past, present, and future concentrations of tropospheric ozone and aerosols: Methodology, ozone evaluation, and sensitivity to aerosol wet removal, J. Geophys. Res., 111, D22, doi:10.1029/2005JD006937, 2006.

Hoskins, B. and Hodges, K.: New perspectives on the Northern Hemisphere winter storm tracks, J. Atmos. Sci., 59, 1041-1061, doi:10.1175/1520-0469(2002)059<1041:NPOTNH>2.0.CO;2, 2002.

Hurrell, J., Kushnir, Y., Ottersen, G. and Visbeck, M.: The North Atlantic Oscillation: Climate Significance and Environmental Impact, vol. 134., Eds. Geophysical Monograph Series, 2003.

Inness, A., Flemming, J., Suttie, M., and Jones, L.: GEMS data assimilation system for chemically reactive gases, ECMWF RD Tech Memo 587, 2009.

Inness, A., Baier, F., Benedetti, A., Bouarar, I., Chabrillat, S., Clark, H., Clerbaux, C., Coheur, P., Engelen, R. J., Errera, Q., Flemming, J., George, M., Granier, C., Hadji-Lazaro, J., Huijnen, V., Hurtmans, D., Jones, L., Kaiser, J. W., Kapsomenakis, J., Lefever, K., Leitão, J., Razinger, M., Richter, A., Schultz, M. G., Simmons, A. J., Suttie, M., Stein, O., Thépaut, J.-N., Thouret, V., Vrekoussis, M., Zerefos, C., and the MACC team: The MACC reanalysis: an 8 yr data set of atmospheric composition, Atmos. Chem. Phys., 13, 4073-4109, doi:10.5194/acp-13-4073-2013, 2013.

Jia, Y., Rahn, K., He, K., Wen, T., and Wang, Y.: A novel technique for quantifying the regional component of urban aerosol solely from its sawtooth cycles, J. Geophys. Res., 113, D21, doi:10.1029/2008JD010389, 2008.

Kaiser, J., Heil, A., Schultz, M., Stein, O., van der Werf, G., Wooster, M., and $\mathrm{Xu}, \mathrm{W}$.: Final report on implementation and quality of the D-FIRE assimilation system, MACC deliverable D D-FIRE 7, ECMWF, available at: http://gmes-atmosphere.eu/ documents/deliverables/d-fire/D-FIRE_final_report_v7.pdf (last access: 18 March 2014), 2011. 
Kinnison, D. E., Brasseur, G. P., Walters, S., Garcia, R. R., Marsh, D. R., Sassi, F., Harvey, V. L., Randall, C. E., Emmons, L., Lamarque, J. F., Hess, P., Orlando, J. J., Tie, X. X., Randel, W., Pan, L. L., Gettelman, A., Granier, C., Diehl, T., Niemeier, U., and Simmons, A. J.: Sensitivity of chemical tracers to meteorological parameters in the MOZART-3 chemical transport model, J. Geophys. Res., 112, D20, doi:10.1029/2006JD007879, 2007.

Knowland, K. E., Doherty,R. M., and Hodges, K. I.: Seasonal variation of storm tracks and composition related to the NAO, in preparation, 2015.

Kumar, A., Wu, S., Weise, M. F., Honrath, R., Owen, R. C., Helmig, D., Kramer, L., Val Martin, M., and Li, Q.: Free-troposphere ozone and carbon monoxide over the North Atlantic for 20012011, Atmos. Chem. Phys., 13, 12537-12547, doi:10.5194/acp13-12537-2013, 2013.

Lamarque, J. F. and Hess, P. G.: Arctic oscillation modulation of the northern hemisphere spring tropospheric ozone, Geophys. Res. Lett., 31, 6, doi:10.1029/2003GL019116, 2004.

Lamarque, J.-F., Kiehl, J. T., Brasseur, G. P., Butler, T., CameronSmith, P., Collins, W. D., Collins, W. J., Granier, C., Hauglustaine, D., Hess, P. G., Holland, E. A., Horowitz, L., Lawrence, M. G., McKenna, D., Merilees, P., Prather, M. J., Rasch, P. J., Rotman, D., Shindell, D., and Thornton, P.: Assessing future nitrogen deposition and carbon cycle feedback using a multimodel approach: Analysis of nitrogen deposition, J. Geophys, Res., 110, D19, doi:10.1029/2005JD005825, 2005.

Leibensperger, E. M., Mickley, L. J., and Jacob, D. J.: Sensitivity of US air quality to mid-latitude cyclone frequency and implications of 1980-2006 climate change, Atmos. Chem. Phys., 8, 7075-7086, doi:10.5194/acp-8-7075-2008, 2008.

Li, Q., Jacob, D., Bey, I., Palmer, P., Duncan, B., Field, B., Martin, R., Fiore, A., Yantosca, R., Parrish, D., Simmonds, P., and Oltmans, S.: Transatlantic transport of pollution and its effects on surface ozone in Europe and North America, J. Geophys. Res., 107,D13, doi:10.1029/2001JD001422, 2002.

Li, Q., Jacob, D., Park, R., Wang, Y., Heald, C., Hudman, R., Yantosca, R., Martin, R., and Evans, M.: North American pollution outflow and the trapping of convectively lifted pollution by upper-level anticyclone, J. Geophys. Res., 110, D10301, doi:10.1029/2004JD005039, 2005.

Lin, M., Fiore, A. M., Cooper, O. R., Horowitz, L. W., Langford, A. O., Levy, H., Johnson, B. J., Naik, V., Oltmans, S. J., and Senff, C. J.: Springtime high surface ozone events over the western United States: Quantifying the role of stratospheric intrusions, J. Geophys. Res., 117, D21, doi:10.1029/2012JD018151, 2012a.

Lin, M., Fiore, A. M., Horowitz, L. W., Cooper, O. R., Naik, V., Holloway, J., Johnson, B. J., Middlebrook, A. M., Oltmans, S. J., Pollack, I. B., Ryerson, T. B., Warner, J. X., Wiedinmyer, C., Wilson, J., and Wyman, B.: Transport of Asian ozone pollution into surface air over the western United States in spring, J. Geophys. Res., 117, D21, doi:10.1029/2011JD016961, 2012 b.

Lin, M., Horowitz, L. W., Oltmans, S. J., Fiore, A. M., and Fan, S.: Tropospheric ozone trends at mauna loa observatory tied to decadal climate variability. Nat. Geosci., 7, 136-143, 2014.

Manobianco, J.: Explosive east coast cyclogenesis over the westcentral North Atlantic Ocean: a composite study derived from ECMWF operational analyses, Mon. Weather Rev., 117, 2365$2383,1989$.
Marenco, A., Thouret, V., Nédélec, P., Smit, H., Helten, M., Kley, D., Karcher, F., Simon, P., Law, K., Pyle, J., Poschmann, G., Von Wrede, R., Hume, C., and Cook, T.: Measurement of ozone and water vapor by Airbus in-service aircraft: the MOZAIC airborne program, an overview, J. Geophys. Res., 103, 2563125642, doi:10.1029/98JD00977, 1998.

Mickley, L., Jacob, D., Field, B., and Rind, D.: Effects of future climate change on regional air pollution episodes in the United States, Geophys. Res. Lett., 31, L24103, doi:10.1029/2004GL021216, 2004.

Monks, P. S.: A review of the observations and origins of the spring ozone maximum, Atmos. Environ., 34, 3545-3561, 2000.

Monks, P. S., Granier, C., Fuzzi, S., Stohl, A., Williams, M. L., Akimoto, H., Amann, M., Baklanov, A., Baltensperger, U., Bey, I., Blake, N., Blake, R. S., Carslaw, K., Cooper, O. R., Dentener, F., Fowler, D., Fragkou, E., Frost, G. J., Generoso, S., Ginoux, P., Grewe, V., Guenther, A., Hansson, H. C., Henne, S., Hjorth, J., Hofzumahaus, A., Huntrieser, H., Isaksen, I. S. A., Jenkin, M. E., Kaiser, J., Kanakidou, M., Klimont, Z., Kulmala, M., Laj, P., Lawrence, M. G., Lee, J. D., Liousse, C., Maione, M., McFiggans, G., Metzger, A., Mieville, A., Moussiopoulos, N., Orlando, J. J., O’Dowd, C. D., Palmer, P. I., Parrish, D. D., Petzold, A., Platt, U., Pöschl, U., Prévôt, A., Reeves, C. E., Reimann, S., Rudich, Y., Sellegri, K., Steinbrecher, R., Simpson, D., ten Brink, H., Theloke, J., van der Werf, G. R., Vautard, R., Vestreng, V., Vlachokostas, Ch., and von Glasow, R.: Atmospheric composition change - global and regional air quality, Atmos. Environ., 43, 5268-5350, doi:10.1016/j.atmosenv.2009.08.021, ACCENT Synthesis, 2009.

Morcrette, J.-J., Boucher, O., Jones, L., Salmond, D., Bechtold, P., Beljaars, A., Benedetti, A., Bonet, A., Kaiser, J. W., Razinger, M., Schulz, M., Serrar, S., Simmons, A. J., Sofiev, M., Suttie, M., Tompkins, A. M., and Untch, A.: Aerosol analysis and forecast in the European Centre for Medium-Range Weather Forecasts Integrated Forecast System: Forward modeling, J. Geophys. Res., 114, D6, doi:10.1029/2008JD011235, 2009.

Moss, R. H., Edmonds, J. A., Hibbard, K. A., Manning, M. R., Rose, S. K., van Vuuren, D. P., Carter, T. R., Emori, S., Kainuma, M., Kram, T., Meehl, G. A., Mitchell, J. F. B., Nakicenovic, N., Riahi, K., Smith, S. J., Stouffer, R. J., Thomson, A. M., Weyant, J. P., and Wilbanks, T. J.: The next generation of scenarios for climate change research and assessment, Nature, 463, 747-756, 2010.

Nedelec, P., Cammas, J.-P., Thouret, V., Athier, G., Cousin, J.-M., Legrand, C., Abonnel, C., Lecoeur, F., Cayez, G., and Marizy, C.: An improved infrared carbon monoxide analyser for routine measurements aboard commercial Airbus aircraft: technical validation and first scientific results of the MOZAIC III programme, Atmos. Chem. Phys., 3, 1551-1564, doi:10.5194/acp-3-15512003, 2003.

Oltmans, S., Lefohn, A., Harris, J., Galbally, I., Scheel, H., Bodeker, G., Brunke, E., Claude, H., Tarasick, D., Johnson, B., Simmonds, P., Shadwick, D., Anlauf, K., Hayden, K., Schmidlin, F., Fujimoto, T., Akagi, K., Meyer, C., Nichol, S., Davies, J., Redondas, A., and Cuevas, E.: Long-term changes in tropospheric ozone, Atmos. Environ., 40, 3156-3173, doi:10.1016/j.atmosenv.2006.01.029, 2006.

Owen, R. C., Cooper, O. R., Stohl, A., and Honrath, R. E.: An analysis of the mechanisms of North American pollutant transport 
to the central North Atlantic lower free troposphere, J. Geophys. Res., 111, D23S58, doi:10.1029/2006JD007062, 2006.

Parrish, D. D., Law, K. S., Staehelin, J., Derwent, R., Cooper, O. R., Tanimoto, H., Volz-Thomas, A., Gilge, S., Scheel, H.-E., Steinbacher, M., and Chan, E.: Long-term changes in lower tropospheric baseline ozone concentrations at northern mid-latitudes, Atmos. Chem. Phys., 12, 11485-11504, doi:10.5194/acp-1211485-2012, 2012.

Pausata, F. S. R., Pozzoli, L., Vignati, E., and Dentener, F. J.: North Atlantic Oscillation and tropospheric ozone variability in Europe: model analysis and measurements intercomparison, Atmos. Chem. Phys., 12, 6357-6376, doi:10.5194/acp-12-63572012, 2012.

Polvani, L. M. and Esler, J. G.: Transport and mixing of chemical air masses in idealized baroclinic life cycles, J. Geophys. Res., 112, D23, doi:10.1029/2007JD008555, 2007.

Prather, M. J., Ehhalt, D., Dentener, F., Derwent, R., Dlugokencky, E., Holland, E., Isaksen, I., Katima, J., Kirchoff, V., Matson, P., Midgley, P., and Wang, M.: Atmospheric chemistry and greenhouse gases, in: Climate Change 2001: The Scientific Basis, Contribution of Working Group 1 to the Third Assessment Report of the Intergovernmental Panel on Climate Change, edited by: Houghton, J. T., Ding, Y., Griggs, D. J., Noguer, M., van der Linden, P. J., Dai, X., Maskell, K. and Johnson, C. A., Cambridge University Press, Cambridge, UK, 239-288, 2001.

Price, C., Penner, J., and Prather, M.: $\mathrm{NO}_{\mathrm{x}}$ from lightning: 1. Global distribution based on lightning physics, J. Geophys. Res., 102, 5929-5941, doi:10.1029/96JD03504, 1997.

Schultz, D.: Reexamining the cold conveyor belt, Mon. Weather Rev., 129, 2205-2225, 2001.

Schultz, D., Keyser, D. and Bosart, L.: The effect of large-scale flow on low-level frontal structure and evolution in midlatitude cyclones, Mon. Weather Rev., 126, 1767-179, 1998.

Serreze, M.: Climstological aspects of cyclone and development and decay in the Arctic, Atmos. Ocean, 33, 1-23, 1995.

Stein, O.: Model documentation of the MOZART CTM as implemented in the GEMS system, available at: http://gems.ecmwf. int/do/get/PublicDocuments/1531/1172 (last access: 4 November 2013), 2009.

Stein, O., Flemming, J., Inness, A., Kaiser, J. W., and Schultz, M. G.: Global reactive gases forecasts and reanalysis in the MACC project, J. Integr. Environ. Sci., 9, 57-70, doi:10.1080/1943815X.2012.696545, 2012.

Stohl, A.: A 1-year Lagrangian "climatology" of airstreams in the northern hemisphere troposphere and lowermost stratosphere, J. Geophys. Res., 106, 7263-7279, doi:10.1029/2000JD900570, 2001.
Stohl, A. and Trickl, T.: A textbook example of long-range transport: Simultaneous observation of ozone maxima of stratospheric and North American origin in the free troposphere over Europe, J. Geophys. Res., 104, 30445-30462, doi:10.1029/1999JD900803, 1999.

Stohl, A., Hittenberger, M., and Wotawa, G.: Validation of the lagrangian particle dispersion model FLEXPART against largescale tracer experiment data, Atmos. Environ., 32, 4245-4264, doi:10.1016/S1352-2310(98)00184-8, 1998.

Stohl, A., Eckhardt, S., Forster, C., James, P., and Spichtinger, N.: On the pathways and timescales of intercontinental air pollution transport, J. Geophys. Res., 107, ACH 6-1-ACH 6-17, doi:10.1029/2001JD001396, 2002a.

Stohl, A., Eckhardt, S., Forster, C., James, P., Spichtinger, N., and Seibert, P.: A replacement for simple back trajectory calculations in the interpretation of atmospheric trace substance measurements, Atmos. Environ., 36, 4635-4648, doi:10.1016/S13522310(02)00416-8, 2002b.

Tang, Q., Prather, M. J., and Hsu, J.: Stratosphere-troposphere exchange ozone flux related to deep convection, Geophys. Res. Lett., 38, 3, doi:10.1029/2010GL046039, 2011.

Thorncroft, C. D., Hoskins, B. J., and McIntyre, M. E.: Two paradigms of baroclinic-wave life-cycle behaviour, Q. J. Roy. Meteorol. Soc., 119, 17-55, 1993.

van der Werf, G. R., Randerson, J. T., Giglio, L., Collatz, G. J., Mu, M., Kasibhatla, P. S., Morton, D. C., DeFries, R. S., Jin, Y., and van Leeuwen, T. T.: Global fire emissions and the contribution of deforestation, savanna, forest, agricultural, and peat fires (19972009), Atmos. Chem. Phys., 10, 11707-11735, doi:10.5194/acp10-11707-2010, 2010.

Wang, C.-C. and Rogers, J. C.: A composite study of explosive cyclogenesis in different sectors of the North Atlantic. Part I: Cyclone structure and evolution, Mon. Weather Rev., 129, 14811499, 2001.

Zhang, L., Jacob, D. J., Boersma, K. F., Jaffe, D. A., Olson, J. R., Bowman, K. W., Worden, J. R., Thompson, A. M., Avery, M. A., Cohen, R. C., Dibb, J. E., Flock, F. M., Fuelberg, H. E., Huey, L. G., McMillan, W. W., Singh, H. B., and Weinheimer, A. J.: Transpacific transport of ozone pollution and the effect of recent Asian emission increases on air quality in North America: an integrated analysis using satellite, aircraft, ozonesonde, and surface observations, Atmos. Chem. Phys., 8, 6117-6136, doi:10.5194/acp-8-6117-2008, 2008. 